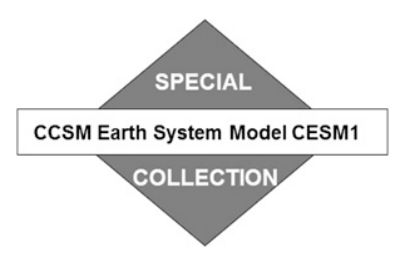

\title{
Greenland Surface Mass Balance as Simulated by the Community Earth System Model. Part I: Model Evaluation and 1850-2005 Results
}

\author{
Miren VizCAíno, ${ }^{*}+{ }^{+}$William H. Lipscomb, ${ }^{\#}$ William J. Sacks, ${ }^{@}$ Jan H. VAN ANGelen, $* *$ \\ BERT WOUTERS, ${ }^{++}$AND MICHIEL R. VAN DEN BROEKE** \\ * Institute for Marine and Atmospheric Research, Utrecht University, Utrecht, Netherlands, and Department of Geography, \\ University of California, Berkeley, Berkeley, California \\ \# Group T-3, Fluid Dynamics and Solid Mechanics, Los Alamos National Laboratory, Los Alamos, New Mexico \\ ${ }^{\circledR}$ National Center for Atmospheric Research, \& Boulder, Colorado \\ ** Institute for Marine and Atmospheric Research, Utrecht University, Utrecht, Netherlands \\ ${ }^{++}$Bristol Glaciology Centre, School of Geographical Sciences, University of Bristol, Bristol, United Kingdom, \\ and Department of Physics, University of Colorado at Boulder, Boulder, Colorado
}

(Manuscript received 15 August 2012, in final form 26 March 2013)

\begin{abstract}
The modeling of the surface mass balance (SMB) of the Greenland Ice Sheet (GIS) requires high-resolution models in order to capture the observed large gradients in the steep marginal areas. Until now, global climate models have not been considered suitable to model ice sheet SMB owing to model biases and insufficient resolution. This study analyzes the GIS SMB simulated for the period 1850-2005 by the Community Earth System Model (CESM), which includes a new ice sheet component with multiple elevation classes for SMB calculations. The model is evaluated against observational data and output from the regional model Regional Atmospheric Climate Model version 2 (RACMO2). Because of a lack of major climate biases, a sophisticated calculation of snow processes (including surface albedo evolution) and an adequate downscaling technique, CESM is able to realistically simulate GIS surface climate and SMB. CESM SMB agrees reasonably well with in situ data from 475 locations $(r=0.80)$ and output from RACMO2 $(r=0.79)$. The simulated mean SMB for $1960-2005$ is $359 \pm 120 \mathrm{Gt} \mathrm{yr}^{-1}$ in the range of estimates from regional climate models. The simulated seasonal mass variability is comparable with mass observations from the Gravity Recovery and Climate Experiment (GRACE), with synchronous annual maximum (May) and minimum (August-September) and similar amplitudes of the seasonal cycle. CESM is able to simulate the bands of precipitation maxima along the southeast and northwest margins, but absolute precipitation rates are underestimated along the southeastern margin and overestimated in the high interior. The model correctly simulates the major ablation areas. Total refreezing represents $35 \%$ of the available liquid water (the sum of rain and melt).
\end{abstract}

\section{Introduction}

The Greenland Ice Sheet stores a volume of water that, if released to the oceans, would raise global sea level on average by $7.3 \mathrm{~m}$ (Bamber et al. 2001). Recent observations show that the Greenland and Antarctic Ice

\footnotetext{
${ }^{+}$Current affiliation: Department of Geoscience and Remote Sensing, Delft Institute of Technology, Delft, Netherlands.

\& The National Center for Atmospheric Research is sponsored by the National Science Foundation.

Corresponding author address: Miren Vizcaíno, Stevinweg 1, 2628 CN Delft, Netherlands.

E-mail: m.vizcaino@tudelft.nl
}

Sheets are losing mass at an increasing rate (Zwally et al. 2005; Shepherd and Wingham 2007; Rignot et al. 2008a; Velicogna 2009; van den Broeke et al. 2009). A substantial contribution to this mass loss comes from the acceleration and thinning of large outlet glaciers and ice streams in Greenland and West Antarctica (Joughin et al. 2003; Scambos et al. 2004; Rignot and Kanagaratnam 2006). Also, the volume and extent of surface melting in Greenland have increased during recent decades (Steffen et al. 2004; Hanna et al. 2005, 2008; van den Broeke et al. 2009). These observations show that ice sheets respond to atmosphere and ocean warming rather quickly, on decadal or annual time scales.

It is generally accepted that global climate models are not yet ready to properly simulate ice sheet surface mass 
balance (SMB), owing to climate biases and insufficient horizontal resolution (van den Broeke et al. 2008a). Regional climate models (RCMs) are the state of the art in the modeling of ice sheet SMB (Box et al. 2006; Ettema et al. 2009; Fettweis 2007; Rae et al. 2012; Lenaerts and van den Broeke 2012; Lenaerts et al. 2012), but they suffer from their dependency on a GCM as external forcing. In most cases, RCMs do not update the topography and glacier mask of the GCMs, and there is often a problem of inconsistency between SMB and topography in long-term runs in comparison to earth system models that include interactive ice sheets. Also, when RCM output is used to force ice sheet models, the SMB is calculated at a fixed topography that can be quite different from the evolving topography of the ice sheet in the host model. While other components of the earth system, such as ocean dynamics, land vegetation, and the carbon cycle, are already standard components of global climate models; ice sheets are not. The only studies with an atmosphere-ocean GCM fully coupled with an ice sheet model are those performed with the Hadley Centre Coupled Model, version 3 (HadCM3) (Ridley et al. 2005), ECHAM3/Large-Scale Geostrophic ocean model (LSG) (Mikolajewicz et al. 2007; Vizcaíno et al. 2008), and ECHAM5/Max Planck Institute Ocean Model (MPIOM) (Vizcaíno et al. 2010). The first two models make use of anomalies for the atmospheric forcing (for the fields of temperature and/or precipitation) and temperature index methods to calculate melt. Only the latter does not require the use of anomalies and uses an energy balance scheme with a simple parameterization for albedo.

The Community Earth System Model (CESM) (Hurrell et al. 2013) now includes a new ice sheet component. In CESM the surface mass balance of glacier surfaces is calculated with an energy balance scheme that includes a sophisticated modeling of surface albedo, as well as percolation and refreezing of meltwater within the snowpack. For this study, the SMB calculation is done in the CESM land surface component, the Community Land Model (CLM), at a horizontal resolution of $\sim 1^{\circ}$ at several fixed elevations. Height corrections to temperature and specific humidity are applied to account for differences in atmospheric forcing that are linked to elevation.

In this study we evaluate the performance of the CESM over the Greenland Ice Sheet for the period 1850-2005. We do so by comparing CESM output to that of a state-ofthe-art regional climate model, the Regional Atmospheric Climate Model version 2 (RACMO2), and observational data from in situ stations and the Gravity Recovery and Climate Experiment (GRACE). RACMO2 is especially adapted for use over ice sheets. The RACMO2 simulated SMB shows very good agreement with independent in situ SMB observations $(N=265$, correlation coefficient $r=0.95)$ (Ettema et al. 2009). The simulated SMB time series combined with ice flux data (Rignot et al. 2008b) are highly correlated with satellite data from GRACE (Velicogna 2009), with $r=0.99$ (van den Broeke et al. 2009).

The outline of this paper is as follows. Section 2 gives a description of the model and the setup of the simulations. Section 3 analyzes the simulated near-surface climate of Greenland and compares it with RACMO2. Section 4 evaluates the surface mass balance of the reference period 1960-2005 by comparison with in situ observations, GRACE data, and output from RACMO2. Section 5 presents the climate and surface mass balance evolution for the whole period of the historical simulation (years 1850-2005). The last section presents a summary and conclusions.

\section{Method}

\section{a. Model}

The fully coupled model CESM1.0 is used for these simulations. The Community Atmosphere Model version 4 (CAM4) (Neale et al. 2013) is run with the finite volume dynamical core at a horizontal resolution of $0.9^{\circ} \times 1.25^{\circ}$, which is also the resolution of the land model, CLM (Oleson et al. 2010). CAM4 discretization is done via finite volumes. The horizontal resolution of the Parallel Ocean Program (POP) ocean model (Smith et al. 2010) and the Los Alamos Sea Ice Model (CICE) (Hunke 2010; Jahn et al. 2012) is approximately $1^{\circ}$, and the horizontal resolution of the ice sheet component, the Glimmer Community Ice Sheet Model (GlimmerCISM) (Rutt et al. 2009), is $5 \mathrm{~km}$. Since the purpose of this paper is to evaluate only the surface mass balance, the ice sheet topography has been kept fixed at presentday measurements (Bamber et al. 2001). Ice sheet flow has not been calculated here but is evaluated in a companion paper by Lipscomb et al. (2013).

The surface mass balance is calculated in the land component (CLM) with an energy balance scheme that includes a sophisticated modeling of snow albedo, the Snow and Ice Aerosol Radiation model (SNICAR) (Flanner and Zender 2006). Each CLM grid cell can contains one or more land surface types or land unit. A new "glacier_mec" land unit type (where "mec" denotes multiple elevations classes) has been added to five previous land units (vegetation, bare soil, urban, lake, and glacier) to compute the surface mass balance of glaciers in several fixed elevation ranges. In the simulation analyzed in this paper, 10 elevation classes have been used, with boundaries at $0,200,400,700,1000,1300,1600,2000,2500$, 3000 , and $10000 \mathrm{~m}$. The SMB at CISM grid resolution is calculated from the CLM SMB at these elevation classes 

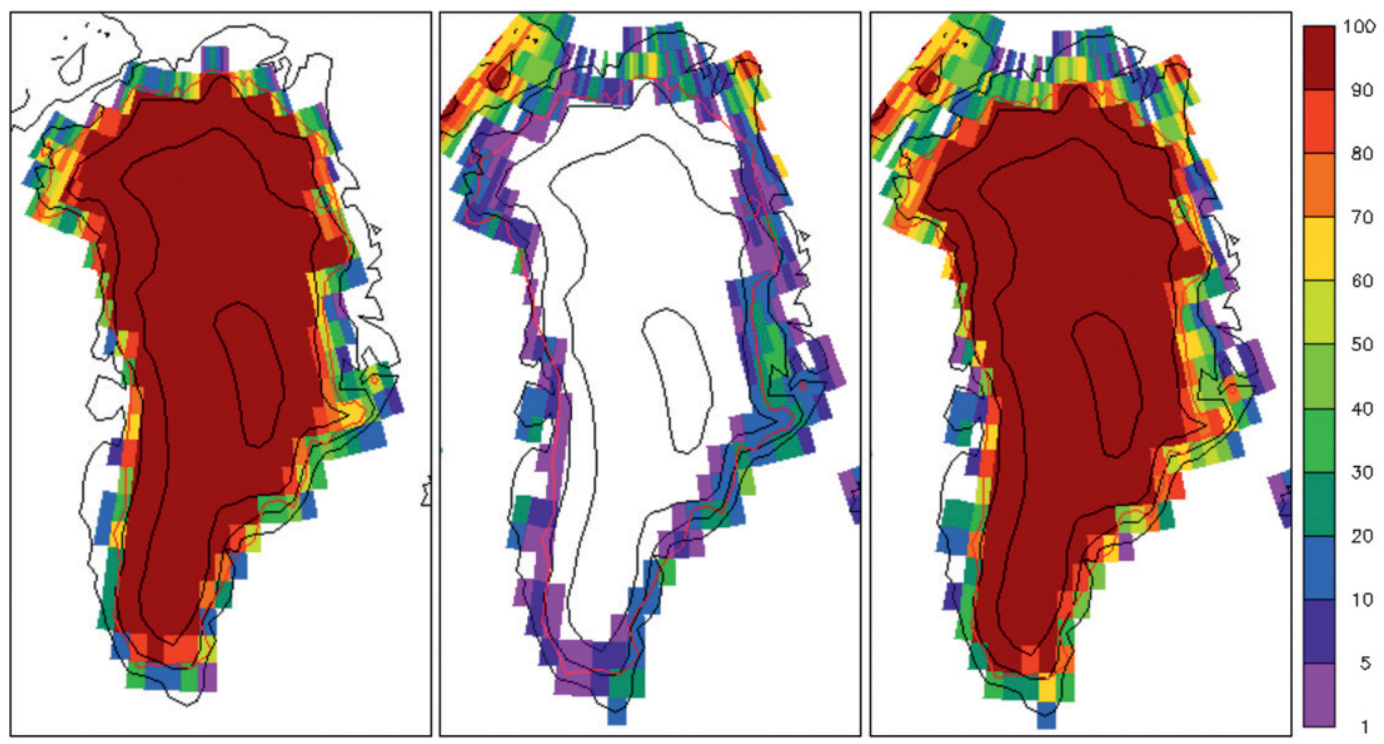

FIG. 1. (left) Ice sheet fraction, (center) fraction of grid cell covered by glaciers and ice caps, and (right) total glacier fraction in the land component of CESM (CLM). The red line delimits $50 \%$ of ice sheet coverage. Elevation contours are plotted in black at $0,1000,2000$, and $3000 \mathrm{~m}$.

by horizontal bilinear and vertical linear interpolations. Further details are given by Lipscomb et al. (2013).

Over Greenland, we replaced the CLM default glacier coverage and surface elevation with data from Bamber et al. (2001). Figure 1 illustrates the glacier cover fraction for each grid cell. The total area of the Greenland Ice Sheet in the model is $1.719 \times 10 \mathrm{~km}^{2}$. The surface mass balance calculation has been built upon the CLM snowpack mass balance scheme. This provides the advantages of model consistency and a more efficient coupling between atmosphere and land, but also means that a true firn model (with snow transitioning to ice over a depth of tens of meters) is not included. The calculation of the SMB of glaciated surfaces, including the Greenland Ice Sheet, is done over two surface types, snow and bare ice, according to

$\mathrm{SMB}($ ice + snow $)=\mathrm{SNOW}+\mathrm{RAIN}-\mathrm{RU}-\mathrm{SU}$,

where SNOW is snowfall, RAIN is rainfall, RU is runoff, and SU is sublimation.

Runoff is calculated as the portion of the available liquid water $(\mathrm{ALW})$ that is not refrozen:

$$
\mathrm{RU}=\mathrm{ALW}-\mathrm{RF}=\mathrm{ME}+\mathrm{RAIN}-\mathrm{RF},
$$

where ME is melt and RF is refreezing. ME is calculated from the sum of surface fluxes (radiative, turbulent, and subsurface heat):

$\mathrm{ME}=\mathrm{SW}_{d}(1-\alpha)+\mathrm{LW}_{d}-\varepsilon \sigma T_{s}^{4}+\mathrm{SHF}+\mathrm{LHF}+\mathrm{GF}$, where $\mathrm{SW}_{d}$ is downwelling shortwave radiation, $\alpha$ is albedo, $\varepsilon=0.97$ is the emissivity of the snow/ice surface, $\sigma$ is the Stefan-Boltzman constant, $T_{s}$ is surface temperature, $\mathrm{LW}_{d}$ is downward longwave radiation, $\mathrm{SHF}$ is sensible heat flux, LHF is latent heat flux, and GF is the subsurface heat flux toward the surface.

Retention of liquid water by capillary forces is considered by means of a parameter (irreducible water saturation) (Anderson 1976) in the equations describing the flow of water between snow layers (Oleson et al. 2010). The snowpack can reach a prescribed maximum thickness $H_{\max }$ over glacier surfaces. Here, $H_{\max }$ has been set to 1-m liquid water equivalent (LWE). If $H_{\max }$ is reached, all additional snowfall is considered ice gain. If the snow depth $H$ becomes zero, then additional melt is considered as ice loss. Melted ice does not refreeze. Percolation and refreezing of meltwater within the snowpack can take place only if $0<H<H_{\max }$. Rainfall falling at a point where $H=H_{\max }$ is not allowed to percolate but runs off.

The maximum number of snow layers is five, and their thickness evolves during the simulations. The calculation of snow albedo is done using the SNICAR model (Flanner and Zender 2006) and takes into account snow grain size, solar angle, and aerosol content. Bare ice albedo is prescribed with two different values for visible and near-infrared frequencies. These values have been set to 0.60 and 0.40 [see Lipscomb et al. (2013) for details] for the present study.

The atmospheric forcing used in the SMB calculation is provided by CAM4 every half hour. From the atmospheric forcing, elevation corrections are applied to 
near-surface temperature (with an assumed lapse rate of $-6 \mathrm{~K} \mathrm{~km}^{-1}$ ) and specific humidity (holding relative humidity constant). Snowfall and rainfall rates, as well as incoming radiation, are not corrected for elevation. Further details are given in Oleson et al. (2010) and Lipscomb et al. (2013).

\section{b. Spinup and simulations setup}

Two simulations of Greenland climate and surface mass balance (SMB) are analyzed: a preindustrial simulation with a length of 100 years and a historical transient simulation covering the period 1850-2005. Both have been performed with the fully coupled model CESM1CISM including interactive calculations of the carbon and nitrogen cycles in the land component and of glacier surface mass balance in different elevation classes.

To obtain initial conditions for the preindustrial simulation, it was necessary to spin up the carbon cycle and the ocean, as well as the snowpack over glaciated surfaces at multiple elevation columns. For this purpose, the initial conditions for all model components except CLM were taken from an existing preindustrial simulation with CESM (without the new land ice component and the new land units with multiple elevation classes over glaciated surfaces). To initialize with a spunup snowpack, the initial conditions coming from this coupled preindustrial run were blended with another simulation that was performed with CLM including glacier_mec land units but forced offline with atmospheric data from the same coupled CESM simulation. This offline CLM simulation had a length of $\sim 120$ years, sufficient for spinning up the snowpack. It was started with a snowpack of thickness $H=H_{\max } / 2=0.5 \mathrm{~m}$ over glacier_mec land units, so as to minimize the time needed for spinup, and a snow temperature of $-10^{\circ} \mathrm{C}$ in all layers.

All of the simulations analyzed in this study used an updated dataset for topography and ice sheet coverage over Greenland (Bamber et al. 2001). For this reason, the glacier coverage used to generate the atmospheric forcing for the offline glacier_mec simulation with GLAC_MEC is inconsistent with the glacier coverage in the preindustrial run, and the first half of this simulation was discarded prior to for analysis since the model is still equilibrating.

The historical simulation is branched from year 100 of the preindustrial simulation. The transient external forcing consists of insolation, volcanic eruptions, aerosols, and long-lived greenhouse gas concentrations.

\section{c. Data for model evaluation}

For evaluation of the model, the period between years 1960 and 2005 is used. The model output is evaluated using results from a regional model, RACMO2, which has been thoroughly evaluated against available in situ observations (Ettema et al. 2009, 2010a), GRACE data (van den Broeke et al. 2009), and other satellite measurements (Fettweis et al. 2011).

RACMO2 and preceding model versions have been applied to several studies of the Greenland Ice Sheet (Ettema et al. 2009; van den Broeke et al. 2009). The version used in this study has an improved simulation of surface albedo (van Angelen et al. 2012). RACMO2 is forced at the boundaries with data from the 40-yr European Centre for Medium-Range Weather Forecasts (ECMWF) Re-Analysis (ERA-40) (Uppala et al. 2005) up to 1979 and with the ECMWF Interim Re-Analysis (ERA-Interim) (Simmons et al. 2007) thereafter. The model is run with a horizontal resolution close to $11 \mathrm{~km}$, which is the highest among available simulations from regional models for Greenland that include an interactive snow model.

The climate fields and terms of surface mass balance over glacier land units that are plotted and analyzed in this paper have been averaged over different elevation classes, weighted by the fractional area at each elevation computed from a high-resolution topographic dataset. Unless otherwise specified, these fields are plotted only over grid cells belonging to the ice sheet with glacier coverage of at least $1 \%$.

Note that RACMO2 has been forced by reanalysis data, which assimilates data from observations. This limits the natural variability of the large-scale climate to a state that might be quite different from the single CESM realization analyzed in this paper.

\section{Simulated near-surface climate of Greenland}

We first focus on near-surface $(2 \mathrm{~m})$ atmospheric temperature and the surface energy balance. The latter determines melt rates and surface temperature. Special emphasis is given to the summer energy fluxes since they are most important for ice sheet ablation. The surface albedo is mentioned here, but it is analyzed in more detail in the following section because of its strong ties with melt, snowfall, and rainfall. The Greenland climate and energy fluxes as simulated by RACMO2 are discussed and evaluated in detail by Ettema et al. (2010b).

Analysis of temperature and surface fluxes is done with the data provided by CESM for each land grid cell. The mean values represent the area-weighted average of all surface types in each grid cell, including vegetated as well as glaciated areas. Therefore, these mean values contain information from areas outside the ice sheet. The surface mass balance scheme uses values for the incoming radiation that are shared by all surface types, but upward radiation and net turbulent fluxes are 

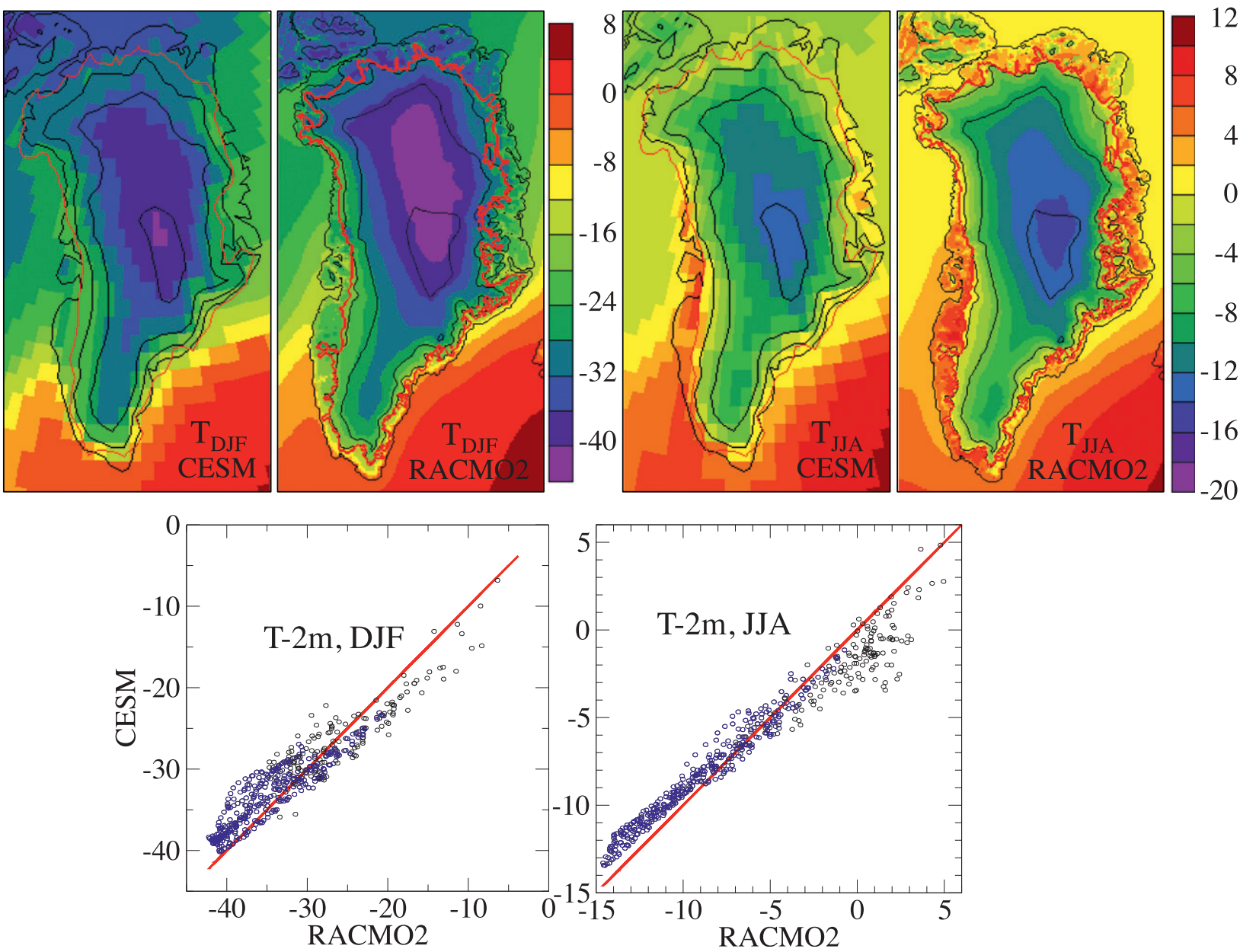

FIG. 2. Mean 1960-2005 near-surface temperature $\left({ }^{\circ} \mathrm{C}\right)$ as simulated by CESM and RACMO2: (top left pair) winter (DJF) and (top right pair) summer (JJA) and (bottom) scatterplots for land points with $>20 \%$ (black) and $>99 \%$ (blue) ice sheet coverage. The red line in the scatterplot represents the 1:1 fit. Note the different intervals of the color bars $\left(4^{\circ} \mathrm{C}\right.$ for winter and $2^{\circ} \mathrm{C}$ for summer $)$. Over land, values represent the weighted average over the different land surface types. Elevation contours are plotted in black at 0,1000, 2000, and 3000 $\mathrm{m}$. Red lines delimits $50 \%$ ice sheet cover.

calculated specifically for each surface type. In the analysis of the correlation between CESM and RACMO2 fluxes, two cases will be considered in order to evaluate the influence of the model biases over noniced surfaces. For the first case, grid cells with partial ice sheet coverage (defined as higher than $20 \%$ ) will be considered; for the second, we include only grid cells with total ice sheet coverage (defined as higher than 99\%).

The area of CESM grid points over the ice sheet decreases with increasing latitude, ranging between $\sim 3000$ and $\sim 6000 \mathrm{~km}^{2}$. The number of RACMO2 grid points for the Greenland Ice Sheet (GIS) is 13 962. The number of CESM (land model) grid points with more than $50 \%$ glacier cover is 431 . The highest RACMO2 grid point is at $3227 \mathrm{~m}$ and at $3142 \mathrm{~m}$ in CESM. The median heights are 2098 and $1928 \mathrm{~m}$, respectively, and the interquartile ranges are 998 (RACMO2) and $1111 \mathrm{~m}$ (CESM).

\section{a. Near-surface temperature}

The simulated mean winter, December-February (DJF), near-surface temperature over the GIS is $-31.2^{\circ} \mathrm{C}$, only $0.4^{\circ} \mathrm{C}$ higher than for RACMO2. The pattern agrees well with RACMO2 (the correlation coefficient is $r=0.95$ ). CESM simulates higher temperatures over the northern interior of the ice sheet (Fig. 2), very likely because of the smoothed topography. Near-surface temperatures over the ocean around Greenland are lower in CESM. At the margins of the ice sheet and in the southern interior, temperatures are also lower. The RMSE is $2.7^{\circ} \mathrm{C}$ for grid cells with more than $20 \%$ of ice sheet coverage and $2.5^{\circ} \mathrm{C}$ for grid cells with total ice sheet coverage. The colder climate on the eastern side of Greenland compared to the western side at the same altitude and latitude (Ettema et al. 2010b) does not have a corresponding pattern in CESM. 
TABLE 1. Analysis of summer (JJA) surface energy fluxes averaged over years 1960-2005. RACMO2 values have been previously averaged over each CESM grid cell. The correlation coefficient $r$ is given for points with glacier fractions (gf) of at least 0.20 and 0.99 . CESM mean is the area-weighted average of land values over the ice sheet, with these land values being area-weighted averages over the different land types; $\mathrm{SW}_{d}$ is incoming solar radiation; $\mathrm{SW}_{\text {net }}$ is absorbed solar radiation; $\mathrm{LW}_{d}$ is incoming longwave radiation; $\mathrm{LW}_{\text {net }}$ is the absorbed longwave radiation; $R_{\text {net }}$ is net radiation; SHF is sensible latent flux; LHF is latent heat flux; and GF is subsurface heat flux.

\begin{tabular}{lcccr}
\hline \hline Fluxes & CESM mean & CESM mean - RACMO2 mean & $r(\mathrm{gf}>0.20) / r(\mathrm{gf}>0.99)$ & RMSE $(\mathrm{gf}>0 / 20) / \mathrm{RMSE}(\mathrm{gf}>0.99)$ \\
\hline $\mathrm{SW}_{d}$ & 268 & -11 & $0.77 / 0.54$ & $16 / 17$ \\
$\mathrm{SW}_{\text {net }}$ & 61 & -3 & $0.76 / 0.73$ & $20 / 7$ \\
$\mathrm{LW}_{d}$ & 235 & +7 & $0.92 / 0.83$ & 14 \\
$\mathrm{LW}_{\text {net }}$ & -46 & +6 & $0.51 / 0.71$ & $9 / 9$ \\
$R_{\text {net }}$ & 15 & +4 & $0.79 / 0.61$ & 21 \\
SHF & 7 & +0.2 & $0.21 / 0.76$ & $10 / 5$ \\
LHF & -8 & -3 & $0.61 / 0.65$ & $5 / 4$ \\
GF & -1.4 & -1.2 & $0.09 / 0.62$ & $8 / 5$ \\
\hline
\end{tabular}

The simulated mean summer, June-August (JJA), near-surface temperature over the GIS is $-7.1^{\circ} \mathrm{C}$, which is $0.2^{\circ} \mathrm{C}$ higher than for RACMO2. The correlation with RACMO2 data is higher than for winter $(r=0.98)$ and the RMSE is smaller $\left(1.3^{\circ} \mathrm{C}\right)$. The spatial standard deviation (STD) is also smaller during summer $\left(2.9^{\circ}\right.$ and $6.1^{\circ} \mathrm{C}$ ). Both STDs are smaller than in RACMO2 (summer and winter values of $3.5^{\circ}$ and $7.7^{\circ} \mathrm{C}$ ). The mean summer bias is $0.65^{\circ} \mathrm{C}$. The RMSE is only slightly reduced when considering grid cells with more than $99 \%$ of ice sheet coverage $\left(1.1^{\circ} \mathrm{C}\right)$. As in winter, temperatures are higher in CESM over the northern interior and lower over the rest of the ice sheet. Ocean temperatures around Greenland are also lower in CESM. Over the tundra, there are major discrepancies between models in the north where CESM temperatures range between $-4^{\circ}$ and $0^{\circ} \mathrm{C}$, while RACMO2 simulates temperatures in the range of $2^{\circ}-4^{\circ} \mathrm{C}$. These lower temperatures in CESM can be at least in part attributed to the presence of sea ice at these northern latitudes in CESM (as evidenced by negative temperatures over the ocean). Also, the large glacier fraction within the grid cells containing tundra surfaces (see Fig. 1) causes major cooling of the cell-averaged climate (e.g., incoming longwave radiation). In the western tundra these glacier fractions are smaller, and the temperature bias is less.

\section{b. Surface fluxes}

The simulated mean summer downwelling shortwave radiation $\mathrm{SW}_{d}$ for years $1960-2005$ is $268 \mathrm{~W} \mathrm{~m}^{-2}$, which is $11 \mathrm{~W} \mathrm{~m}^{-2}$ lower than for RACMO2 (Table 1). The $\mathrm{SW}_{d}$ shows a south-to-north gradient (Fig. 3, top center) and higher values $\left(>250 \mathrm{~W} \mathrm{~m}^{-2}\right)$ over the ice sheet than in the ice-free areas, caused by clouds. The eastern part of the ice sheet receives more radiation than the western counterpart, also due to different cloud cover. Several minima of $\mathrm{SW}_{d}$ are located in the northwest (NW) and in parts of the western ablation area, as in RACMO2
(Fig. 3, middle center). The correlation with RACMO2 is much higher when areas with partial ice sheet coverage are considered $(0.77$ versus 0.54 for areas totally ice covered). CESM simulates lower $\mathrm{SW}_{d}$ over most of the ice sheet and the areas with partial tundra coverage in the west and higher $\mathrm{SW}_{d}$ over the rest of the partially ice-covered regions. The RMSE is $16 \mathrm{~W} \mathrm{~m}^{-2}\left(17 \mathrm{~W} \mathrm{~m}^{-2}\right.$ if only totally ice-covered regions are considered).

The mean summer albedo is 0.77 , lower than RACMO2 by 0.008 (Table 1). The correlation coefficient is $r=0.78$ ( $r=0.70$ for cells totally ice covered). The RMSE is 0.10 . Over most of the ice sheet, CESM simulates lower albedos. This is in part explained through the high dependence of albedo on snow grain size and, thus, on snow temperature. In the previous subsection, it was shown that the near-surface temperatures in the interior of the ice sheet were higher in CESM. Another process that can explain the lower albedo in CESM is rainfall events. CESM simulates rainfall events in the interior of the ice sheet during summer, a process that is unrealistic because of the low atmospheric temperatures there. For most of the areas where RACMO2 albedos are less than 0.7, CESM albedos are higher. This is likely connected with the lower nearsurface temperatures simulated in ice-free regions of Greenland (see previous subsection), which favor a more persistent snow cover during summer.

The mean absorbed (net) solar radiation $\mathrm{SW}_{\text {net }}$ is $61 \mathrm{~W} \mathrm{~m}^{-2}, 3 \mathrm{~W} \mathrm{~m}^{-2}$ lower than in RACMO2 (Table 1). The $\mathrm{SW}_{\text {net }}$ is minimum in the northern interior of the ice sheet, where the albedo values are high $(\sim 0.825)$ and increases toward the margins, with maximum values $\sim 100 \mathrm{~W} \mathrm{~m}^{-2}$ in the western ablation area where bare ice is exposed during long periods in the summer. The correlation $(r=0.77)$ is similar to that of the albedo and $\mathrm{SW}_{d}$ and decreases $(r=0.73)$ if only totally ice-covered grid cells are considered. The biases are smaller in the interior of the ice sheet (mean bias and RMSE are -1.3 and $7 \mathrm{~W} \mathrm{~m}^{-2}$ for the areas totally ice covered and -5.3 

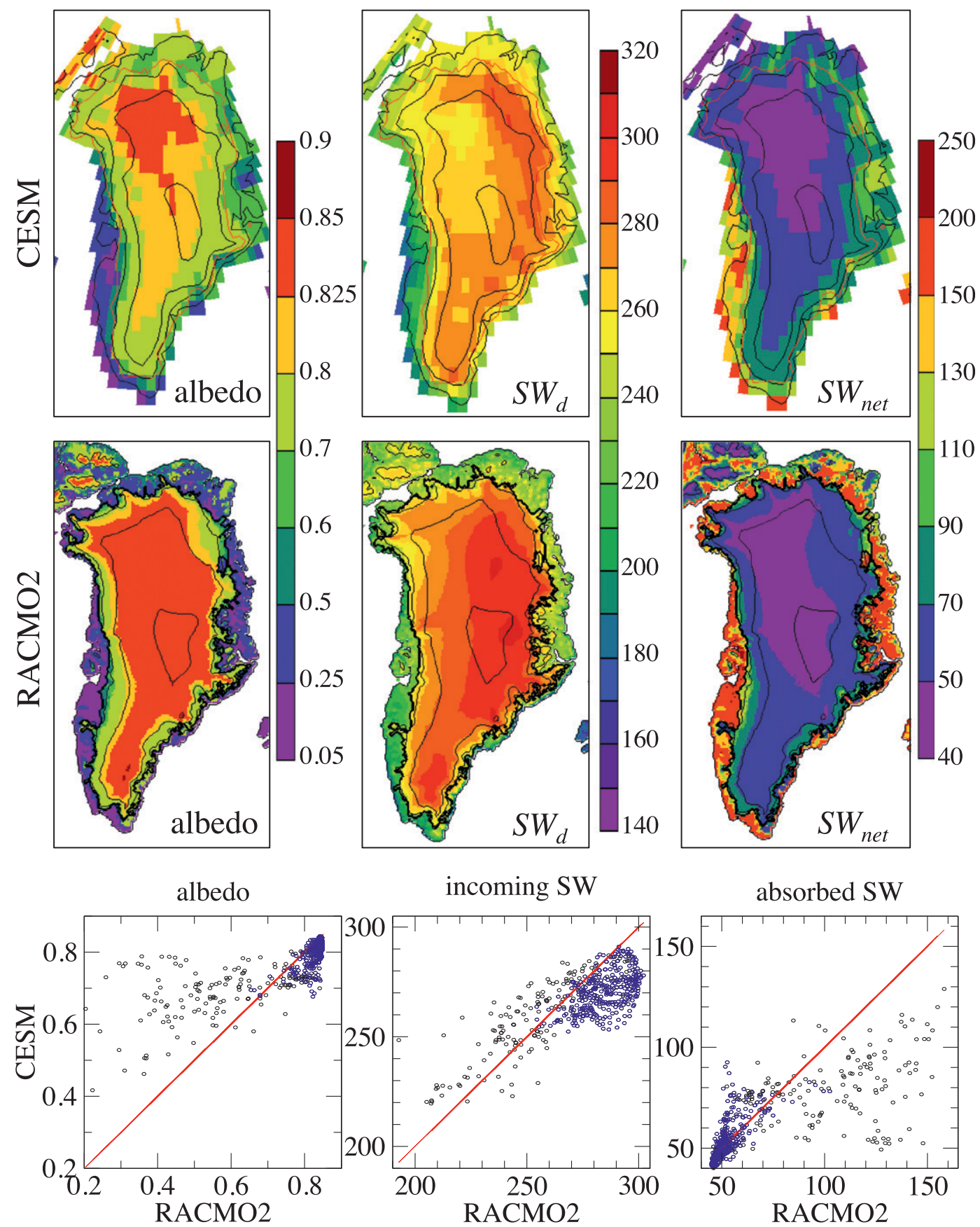

FIG. 3. Summer solar radiation fluxes $\left(\mathrm{W} \mathrm{m}^{-2}\right)$ and surface albedo as simulated by (top) CESM and (middle) RACMO2 averaged over the period 1960-2005. Values from CESM correspond to averages over all land surface types. Color bars are common for CESM and RACMO2. Elevation contours are plotted in black at 0, 1000, 2000, and $3000 \mathrm{~m}$. Red lines delimit 50\% ice sheet cover in CLM. (bottom) Scatterplots are presented (left to right) for albedo and incoming and absorbed SW (blue dots are for grid cells with only ice sheet land type; red line is the 1:1 fit).

and $20 \mathrm{~W} \mathrm{~m}^{-2}$ when considering areas with at least $20 \%$ ice cover). The biases are mostly negative for areas with partial ice sheet coverage, regardless of the positive $\mathrm{SW}_{d}$ biases over most of the margins.
The incoming (downward) longwave radiation $\mathrm{LW}_{d}$ varies over Greenland mainly owing to differences in height (higher elevations receive less radiation because of a thinner overlying atmosphere) and cloudiness, 

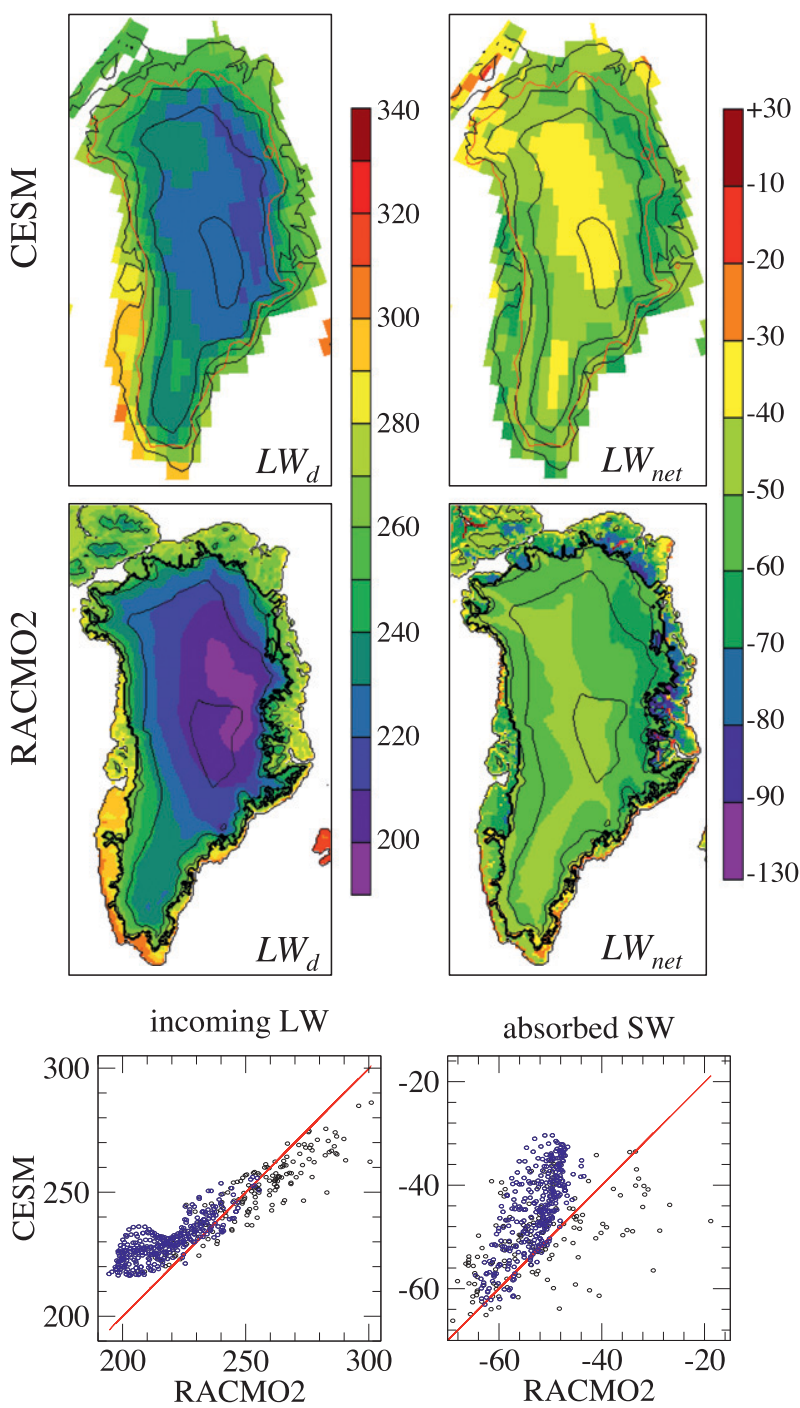

FIG. 4. Summer longwave radiation fluxes and surface albedo as simulated by (top) CESM and (middle) RACMO2 averaged over the period 1960-2005. Values from CESM correspond to averages over all surface types. Elevation contours are plotted in black at 0 , 1000,2000 , and $3000 \mathrm{~m}$; the red line delimits $50 \%$ ice sheet cover. (bottom) Scatterplots are of (left) incoming LW and (right) absorbed SW (blue dots are for grid cells with only ice sheet land type; red line is the $1: 1 \mathrm{fit})$.

which is also often related to the former. The $\mathrm{LW}_{d}$ is also a function of temperature and humidity of the lowest atmosphere layers and especially so of surface elevation. The pattern of $\mathrm{LW}_{d}$ is similar to $\mathrm{SW}_{d}$ but reversed (Figs. 4, top left, and 3, top center). Maximum $\mathrm{LW}_{d}$ is found over the tundra regions in the west and south. Also, as in RACMO2, there is a zonal asymmetry for the northern half of the ice sheet with the minimum $\mathrm{LW}_{d}$ over the high eastern part. Over most of the ice sheet, CESM simulates higher $\mathrm{LW}_{d}$ than in RACMO2, with the largest differences $\left(>20 \mathrm{~W} \mathrm{~m}^{-2}\right)$ in the northern high elevation areas where CESM does not simulate values below $216 \mathrm{~W} \mathrm{~m}^{-2}$. The mean $\mathrm{LW}_{d}\left(235 \mathrm{~W} \mathrm{~m}^{-2}\right)$ is $7 \mathrm{~W} \mathrm{~m}^{-2}$ lower than in RACMO2. The correlation between models is much higher than for $\mathrm{SW}_{d}(r=0.92)$, and the RMSE is similar $\left(14 \mathrm{~W} \mathrm{~m}^{-2}\right)$. Most of the grid cells with partial ice coverage have lower $\mathrm{LW}_{d}$ than in RACMO2.

Over the areas in the north and east that do not belong to the ice sheet, $\mathrm{LW}_{d}$ is slightly lower in CESM, probably for the same reason that $\mathrm{SW}_{d}$ is higher, that is, a relatively high topography that reduces cloud coverage and, additionally, atmospheric thickness. Also, the higher sea ice cover and lower near-surface temperature in CESM described in the previous subsection influence $\mathrm{LW}_{d}$ via lower humidity and temperatures of the lowest atmosphere layers. The link of this relationship between $\mathrm{LW}_{d}$ and $\mathrm{SW}_{d}$ with height will be further explored in future studies, in particular to evaluate the need of a height correction for radiation fluxes for the downscaling to the different elevation classes. As explained in the methods section, radiation is currently kept constant among all elevation classes for CLM glacier units.

The net longwave radiation $\mathrm{LW}_{\text {net }}$ is the difference between the downwelling radiation $\mathrm{LW}_{d}$ and the emitted radiation, which depends on surface temperatures. The $\mathrm{LW}_{d}$ varies between -70 and $-30 \mathrm{~W} \mathrm{~m}^{-2}$ in summer over the ice sheet with the lowest values in the northeast (NE), as in RACMO2 (Fig. 4, middle). In general, the heat loss is higher toward the margins of the ice sheet. Over the western ablation area, however, the heat loss is reduced at the lowest elevations owing to more frequent melting there during summer (van den Broeke et al. 2008a). The mean $\mathrm{LW}_{\text {net }}$ is $-46 \mathrm{~W} \mathrm{~m}^{-2}$, $7 \mathrm{~W} \mathrm{~m}^{-2}$ higher than in RACMO2 (Table 1). The correlation is worse than for $\mathrm{LW}_{d}(r=0.51)$ but it improves dramatically when considering only fully glaciated grid cells $(r=0.71)$. The anomaly pattern is similar to that of $\mathrm{LW}_{d}$. Over the northern high areas in the ice sheet, CESM generates $\mathrm{LW}_{\text {net }}$ that are $>10 \mathrm{~W} \mathrm{~m}^{-2}$ larger than in RACMO2, due to higher $\mathrm{LW}_{d}$ as described above. Over the northern tundra regions, CESM does not simulate the low values simulated in RACMO2, due to the negative temperature bias.

The mean net radiation $R_{\text {net }}$ (i.e., the sum of the net shortwave and longwave surface radiation) is $15 \mathrm{~W} \mathrm{~m}^{-2}$ (Table 1). Lower incoming and net shortwave fluxes over the ice sheet than in RACMO2 added to higher longwave fluxes result in mean net radiation of $15 \mathrm{~W} \mathrm{~m}^{-2}$, which is $4 \mathrm{~W} \mathrm{~m}^{-2}$ higher than in RACMO. The correlation is high $(r=0.79)$. While the annual mean radiation is negative over the ice sheet (not shown), the summer $\mathrm{SW}_{\text {net }}$ exceeds $\mathrm{LW}_{\text {net }}$ over most of the ice sheet, except in a small area in the northern 

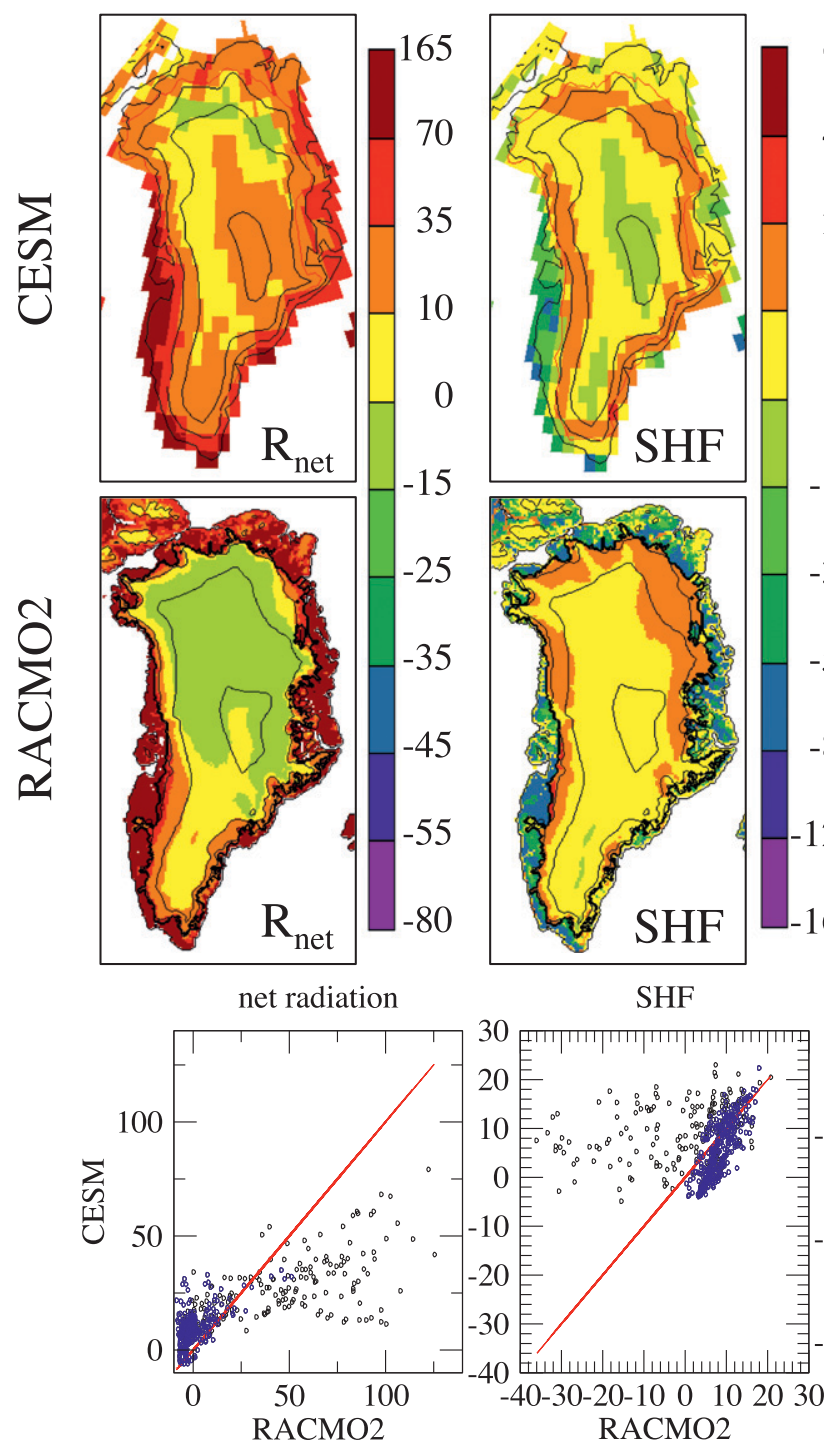
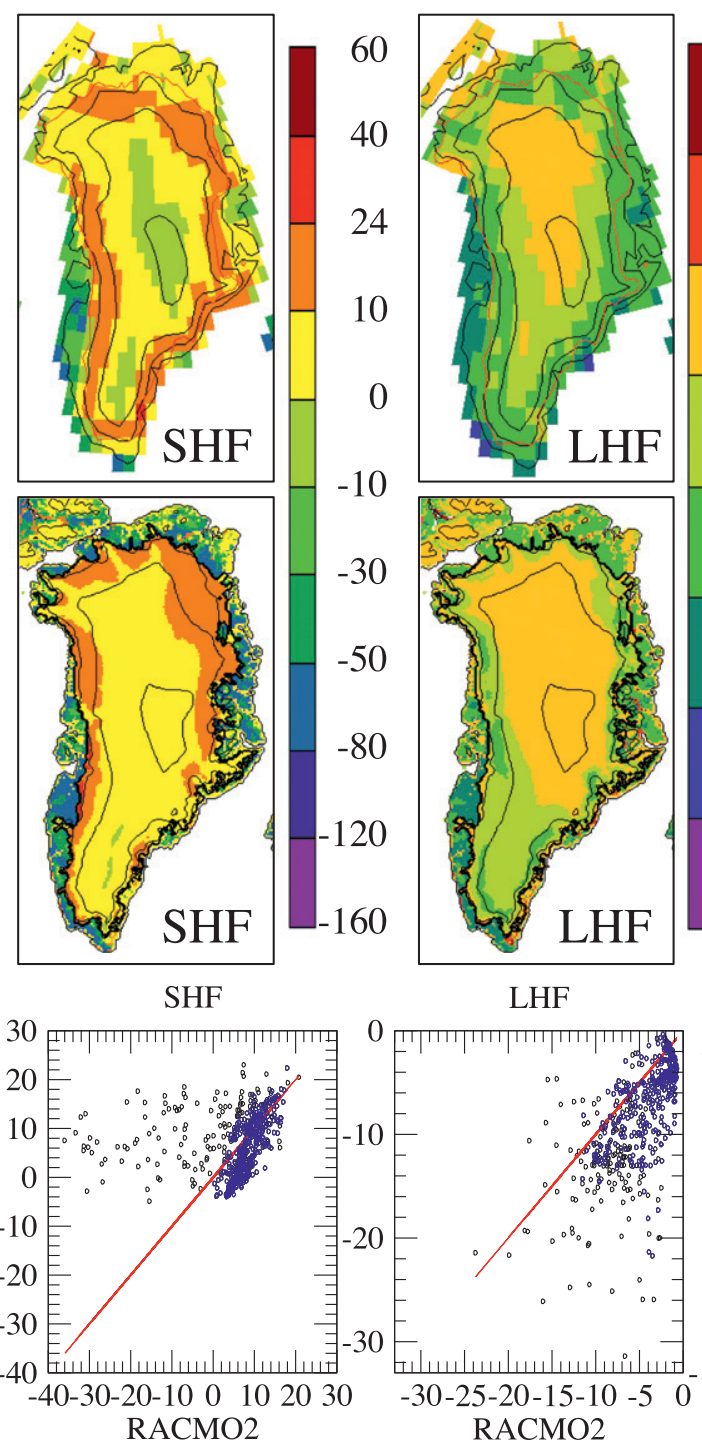

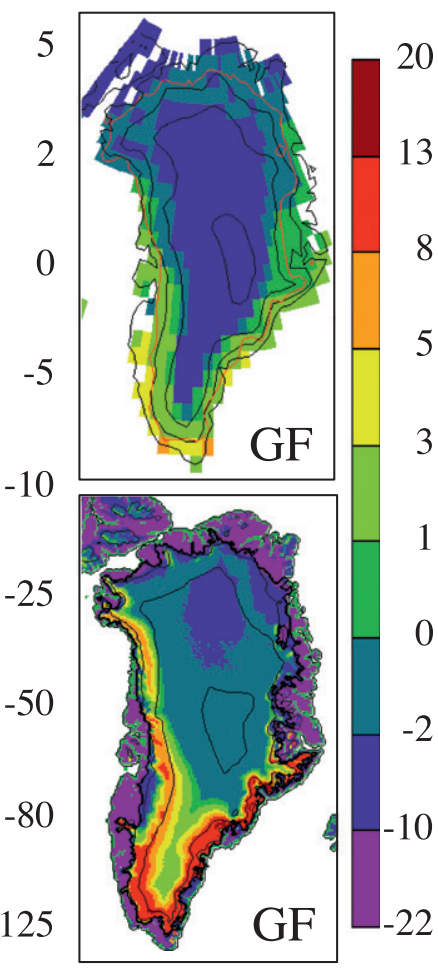

GF

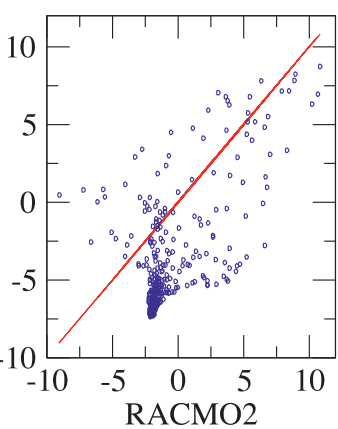

FIG. 5. Summer net surface radiation, turbulent fluxes and subsurface heat flux (GF) $\left(\mathrm{W} \mathrm{m}^{-2}\right.$ ) as simulated by (top) CESM and (middle) RACMO2 averaged over the period 1960-2005 and (bottom) scatterplots. Values from CESM correspond to averages over all land surface types. Elevation contours are plotted in black at 0,1000, 2000, and $3000 \mathrm{~m}$; the red line delimits $50 \%$ ice sheet cover. For GF, only fully glaciated grid cells (blue dots) are included in the scatterplot.

interior with small negative fluxes (Fig. 5, top left). Over the margins, it reaches values close to $70 \mathrm{~W} \mathrm{~m}^{-2}$. The values of $R_{\text {net }}$ agree well with RACMO2 over the ice sheet margins, but they are higher in the interior of the ice sheet, owing to higher $\mathrm{LW}_{d}$ and $\mathrm{LW}_{\text {net }}$ fluxes.

The turbulent sensible (SHF) and latent (LHF) heat fluxes are shown in Fig. 5 (top center left and right panels). The mean SHF $\left(6.6 \mathrm{~W} \mathrm{~m}^{-2}\right)$ is $0.2 \mathrm{~W} \mathrm{~m}^{-2}$ higher than in RACMO2. SHF takes negative values only at the highest elevations over the ice sheet and over most of the ice-free regions. The highest positive values (10$24 \mathrm{~W} \mathrm{~m}^{-2}$ ) are found between 1000 and $2000 \mathrm{~m}$. In RACMO2, these values are also found in the lower part of the ablation areas (Fig. 5, middle left). The discrepancy is due, in part, to partial tundra coverage of the corresponding grid cells in CESM (Fig. 1). The correlation with RACMO2 is low $(r=0.21)$ but improves dramatically when grid cells with partial tundra coverage are excluded $(r=0.76)$. In northern Greenland outside the ice sheet, SHF values are in the same range as in the interior of the ice sheet $\left(0-10 \mathrm{~W} \mathrm{~m}^{-2}\right)$, corresponding to the values that RACMO2 simulates over glaciers and ice caps in this region. The areas covered by tundra in the north reach very negative values in RACMO2 $\left(\sim 100 \mathrm{~W} \mathrm{~m}^{-2}\right)$. CESM does not model comparable negative values in the northern tundra, as it does 
TABLE 2. Components of SMB integrated over the ice sheet in CESM, RACMO2, and other regional models. The equations used for this table are $\mathrm{SMB}($ ice $)+\mathrm{MB}($ snow $)=\mathrm{SNOW}+\mathrm{RAIN}-\mathrm{RU}-\mathrm{SU}$ and $\mathrm{RU}=\mathrm{ALW}-\mathrm{RF}=\mathrm{ME}+\mathrm{RAIN}-\mathrm{RF}$. SMB is computed in CESM as SMB(ice). The figures given in the column other regional models correspond to the studies with the models Modèle Atmosphérique Régional (MAR) (Fettweis 2007), Polar MM5 (PMM5) (Box et al. 2006), and ERA-40 downscaled (Hanna et al. 2008); $r$ and RMSE are the correlation coefficient and RMSE for CESM vs RACMO2. Values in parentheses are standard deviations.

\begin{tabular}{|c|c|c|c|c|c|}
\hline SMB term & CESM 1960-2005 & RACMO2 1960-2005 & Other regional models & $r$ & $\operatorname{RMSE}\left(\mathrm{kg} \mathrm{m}^{-2} \mathrm{yr}^{-1}\right)$ \\
\hline SMB & $359(120)$ & $376(117)$ & $288 / 356 / 287$ & & \\
\hline Snow & $736(74)$ & & & & \\
\hline Rain & $131(22)$ & & $22 / 18 / 28$ & & \\
\hline Precipitation & $866(88)$ & $723(74)$ & $600 / 696 / 610$ & 0.91 & 274 \\
\hline Runoff (RU) & $457(95)$ & $306(86)$ & & 0.69 & 675 \\
\hline Melt (only snow) & $448(70)$ & & & & \\
\hline Melt (snow + ice) & $568(112)$ & $504(111)$ & & 0.73 & 489 \\
\hline Refreezing (RF) & $242(25)$ & $245(38)$ & & & \\
\hline Sublimation (SU) & $54(3)$ & $40(4)$ & $5 / 108 / 38$ & 0.81 & 17 \\
\hline
\end{tabular}

in the western part of the ice sheet and to some extent in the east. This bias will be evaluated together with other biases in surface fluxes in this area of Greenland that have been described above.

The mean summer LHF $\left(-8.3 \mathrm{~W} \mathrm{~m}^{-2}\right)$ is $3 \mathrm{~W} \mathrm{~m}^{-2}$ lower than in RACMO2. LHF is negative all over the ice sheet in summer, indicating sublimation, with the highest absolute values $\left(10-25 \mathrm{~W} \mathrm{~m}^{-2}\right)$ taking place below $2000 \mathrm{~m}$. Over the western ablation area, sublimation decreases slightly toward the margin. This is because sublimation is higher where the snow surface has higher temperatures but is not melting. This pattern is more obvious in RACMO2 owing to increased resolution. The correlation with RACMO2 is moderate $(r=0.61)$, and is the worst of individual fluxes when only areas exclusively ice sheet covered are considered $(r=0.65)$. Outside the ice sheet, absolute LHF values are higher than over the ice sheet. In the west, they are higher (25$\left.50 \mathrm{~W} \mathrm{~m}^{-2}\right)$ than in the east $\left(10-25 \mathrm{~W} \mathrm{~m}^{-2}\right)$, with similar values as in RACMO2. In the north, LHF is less negative than in RACMO2.

The modeling of the subsurface heat flux GF in CESM is conditioned by the limited thickness of the snow cover, which does not exceed $H_{\max }=1-\mathrm{m}$ LWE (section 2). CESM correctly simulates annual mean fluxes that are close to zero in the accumulation zone and represent a net gain for the surface in percolation and ablation areas (not shown) owing to the heat released by refreezing of meltwater in the inner snow layers. The annual mean GF is $1.5 \pm 2.2 \mathrm{~W} \mathrm{~m}^{-2}$, only $0.2 \mathrm{~W} \mathrm{~m}^{-2}$ higher than in RACMO. The correlation between the models is high when only fully glaciated CESM cells are considered ( $r=0.85$ versus $r=0.45$, if partially ice-covered cells are included). Summer GF is less consistent between the two models. Over the real ice sheet, summer GF is negative (heat is subtracted from the surface) in the accumulation zone since the surface is warmer than the inner snow layers. In CESM, GF is also negative over the high south, while positive in RACMO2 (Fig. 5). Over other high areas, CESM shows higher fluxes owing to the shallower snow cover. In the percolation area, where GF is positive because of the heat released by refreezing, CESM shows lower values, in connection with the lower refreezing capacity of its snow cover. The mean summer GF is $-1.4 \mathrm{~W} \mathrm{~m}^{-2}$ (Table 1), $-1.2 \mathrm{~W} \mathrm{~m}^{-2}$ lower than in RACMO2. The correlation between both models is acceptable $(r=0.62$ if only fully glaciated cells are considered).

In summary, summer surface heat fluxes over the Greenland Ice Sheet agree well between CESM and RACMO2, with the major difference being higher net radiative flux in the interior in CESM mainly caused by higher incoming longwave radiation and, in the southern part, also lower surface albedo. Lower incoming solar radiation in CESM only partially offsets this difference.

\section{Simulated 1960-2005 surface mass balance}

The mean surface mass balance for the years 19602005 integrated over the whole ice sheet amounts to $359 \mathrm{Gt} \mathrm{yr}^{-1}$ (Table 2), with a temporal standard deviation of $125 \mathrm{Gt} \mathrm{yr}^{-1}$. Both values agree well with RACMO2 values for the same period $\left(376 \pm 117 \mathrm{Gt} \mathrm{yr}^{-1}\right)$, but this is mainly attributed to compensation of higher precipitation $\left(+143 \mathrm{Gtyr}^{-1}\right)$ with higher runoff $\left(+151 \mathrm{Gt} \mathrm{yr}^{-1}\right)$ and sublimation $\left(+14 \mathrm{Gt} \mathrm{yr}^{-1}\right)$ in CESM.

Figure 6 compares CESM simulated 1960-2005 SMB at 5 -km resolution with data from 475 locations over the GIS (Cogley 2004; Bales et al. 2009; van de Wal et al. 2012; other sources referenced in supplementary material of Ettema et al. 2009). Most of the observational data corresponds to the accumulation zone, with measurement periods varying from location to location. The modeled SMB agrees reasonably well with the observations $(r=$ 0.80). Accumulation rates are overestimated over the 

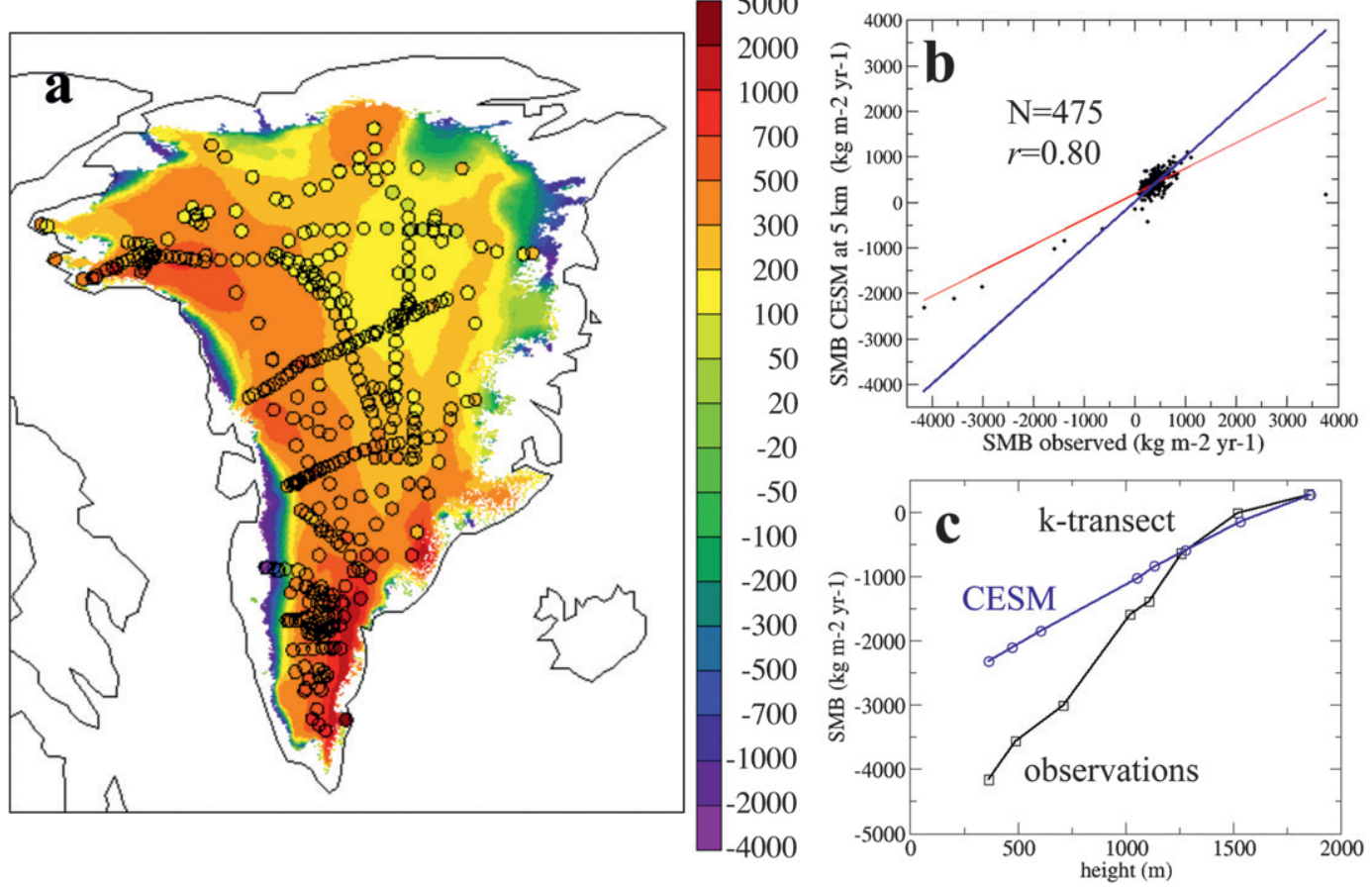

FIG. 6. GIS SMB as modeled by CESM at $5-\mathrm{km}$ resolution and data from 475 stations: (a) surface map and (b) correlation plot. In (b), the blue line indicates the 1:1 fit; the red line is the linear fit. (c) SMB data as a function of elevation from the $\mathrm{K}$ transect at eight locations (van de Wal et al. 2012) (black) and data from the closest points in CESM 5-km grid (blue).

northern interior. CESM reproduces observed accumulation rates in the southern part, except in the highaccumulation area of the southeast (SE) margin, where it fails to reproduce the highest SMB values from this compilation that are close to $4000 \mathrm{~kg} \mathrm{~m}^{-2} \mathrm{yr}^{-1}$ (data from ice core drilled by Jason Box). Figure $6 \mathrm{c}$ shows the comparison with 1990-2007 data from eight stations along the $\mathrm{K}$ transect (van de Wal et al. 2012) in the western ablation and percolation area around $67^{\circ} \mathrm{N}$. The modeled equilibrium line altitude is close to $\sim 1500 \mathrm{~m}$, as in the observations. The SMB differences are relatively small over $1000 \mathrm{~m}$. The SMB gradient is underestimated in CESM, which models too high SMB over the lowest three stations. Two main factors can explain this mismatch. First, these stations are located over a narrow fjord that is framed by tundra. The model resolution is too coarse to reproduce this small-scale feature. Second, these stations are located within the "dark zone" (Wientjes and Oerlemans 2010), which shows values for bare ice albedo that are among the lowest of the ice sheet [between 0.3 and 0.4; see, for instance, Fig. 1 in van Angelen et al. (2012), including MODIS data]. The fixed value of bare ice albedo in CESM ( $~ 0.5$ when averaged over the visible and near-infrared spectra) is too high for this area.

Figure 7 illustrates the map of mean SMB for 19602005 from CLM $\left(\sim 1^{\circ}\right.$ resolution $)$ and CISM $(5-\mathrm{km}$ resolution) outputs. The output from CLM for each grid cell represents area-weighted averages over the elevation classes. The ablation area (i.e., the area with negative SMB) represents $10 \%$ of the ice sheet in CESM and $12 \%$ in RACMO. The ablation areas are similarly distributed in RACMO2 and CESM: the main ablation areas along the western, northern, and northeastern margins have a similar width, while the southeastern margin lacks an ablation area in both models. Also, the small dimension of the ablation areas of the midwestern and northwestern margins, which present high topographic gradients and local maxima for precipitation rates, are similar in both models. Main discrepancies occur in areas of complex topography, as in the mideastern margin, where CESM does not simulate some of the ablation areas captured by RACMO2. The simulated equilibrium line is placed at $\sim 1000 \mathrm{~m}$ in the north and northeast and at $\sim 1500 \mathrm{~m}$ in the southern half of the western margin.

When CESM and RACMO2 data are both interpolated to the $5-\mathrm{km}$ grid, a correlation of $r=0.79$ is found (Fig. 7e; Table 2). The SMB range is substantially smaller in CESM (from -2337 to $1188 \mathrm{~kg} \mathrm{~m}^{-2} \mathrm{yr}^{-1}$ ) than in RACMO (from -3143 to $4405 \mathrm{~kg} \mathrm{~m}^{-2} \mathrm{yr}^{-1}$ ). When the high accumulation areas in RACMO, where the $\mathrm{SMB}>1188 \mathrm{~m}^{-2} \mathrm{yr}^{-1}$ ( $4 \%$ of the ice sheet), are 

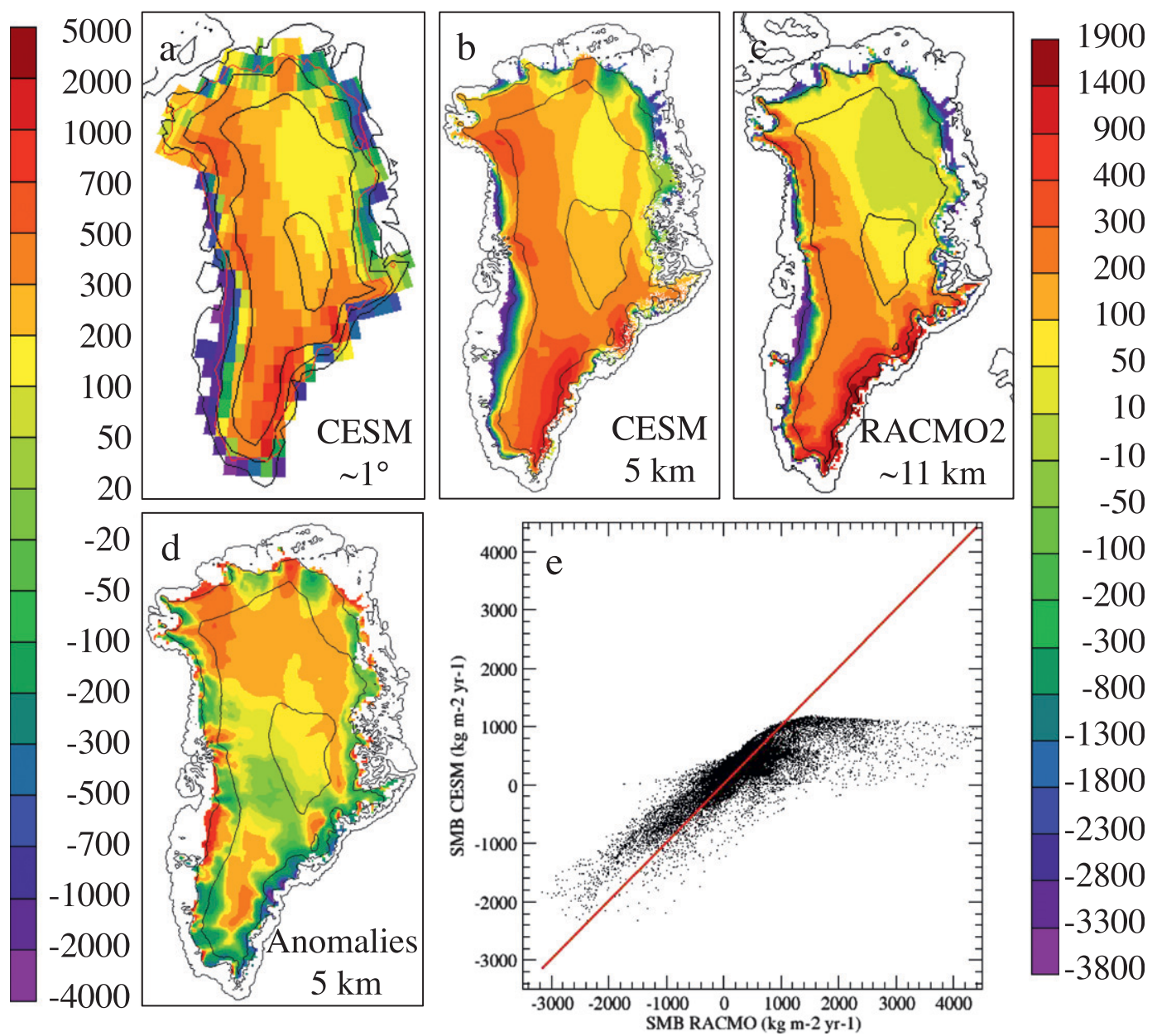

FIG. 7. Mean SMB $\left(\mathrm{kg} \mathrm{m}^{-2} \mathrm{yr}^{-1}\right)$ for 1960-2005: (a) at CLM grid, (b) downscaled at the resolution of the ice sheet grid $(5 \mathrm{~km})$, (c) from RACMO2 ( 11-km resolution), and (d) anomalies CESM minus RACMO2. Elevation contours are plotted every $1000 \mathrm{~m}$; the red lines delimits $50 \%$ ice sheet cover. The left color bar corresponds to (a),(b), and (c); the right color bar corresponds to the anomalies in (d). (e) Scatterplot of SMB from RACMO2 vs CESM in the $5-\mathrm{km}$ grid.

excluded, the correlation improves substantially $(r=$ 0.86), and the RMSE is reduced from 309 to $199 \mathrm{~kg} \mathrm{~m}^{-2} \mathrm{yr}^{-1}$. CESM simulates a higher SMB over the areas where RACMO2 simulates the lowest rates (mean bias $=+508 \mathrm{Gt} \mathrm{yr}^{-1}$ for the $2 \%$ of the ice sheet where $\mathrm{SMB}_{\mathrm{RACMO} 2}<1000 \mathrm{~kg} \mathrm{~m}^{-2} \mathrm{yr}^{-1}$ ).

In the following, precipitation and melt will be analyzed separately. Seasonality and albedo will be evaluated in the two following subsections.

\section{a. Precipitation}

The mean total precipitation over the reference period is $866 \mathrm{Gtyr}^{-1}\left(\mathrm{STD}=88 \mathrm{Gtyr}^{-1}\right)$, which exceeds the range of values from regional models (Table 2), owing to the smoother topography that permits a higher inland penetration of moisture. The precipitation map (Fig. 8) shows two bands of high precipitation along the southeastern and western margins and a strong reduction of precipitation toward the northern interior of the ice sheet, where rates are between 100 and $200 \mathrm{~kg} \mathrm{~m}^{-2} \mathrm{yr}^{-1}$. The model captures the local maxima in the northwest. Rates over $1000 \mathrm{~kg} \mathrm{~m}^{-2} \mathrm{yr}^{-1}$ are modeled along the southeast and southwest margins, as in RACMO2, but miss the peak rates there. Along the northern margin, the model shows a local maximum of more than $500 \mathrm{~kg} \mathrm{~m}^{-2} \mathrm{yr}^{-1}$ that is associated with orography but misses other maxima resolved by RACMO2. The overall pattern agrees well with RACMO2 $(r=0.91)$, with major biases being overestimation of rates in the interior of the ice sheet and underestimation in the southeast, attributed to the smoothed topography of CESM, which prevents the model from fully capturing the processes associated with orographic 

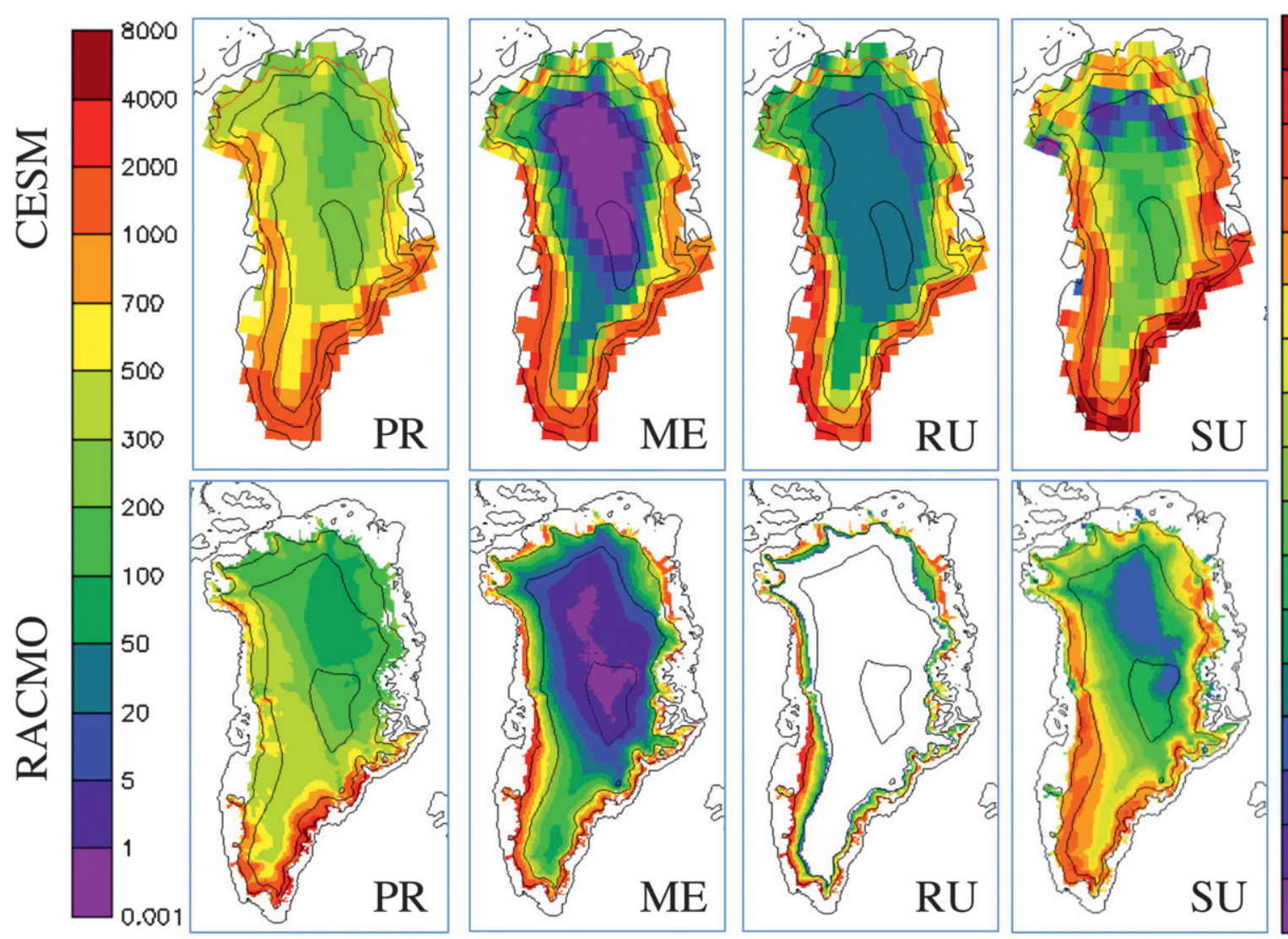

155

120

100

80

60

40

30

20

15

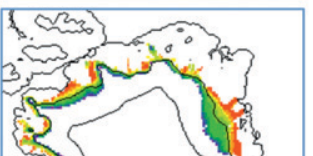

10

5

1

0

$-1$

$-5$
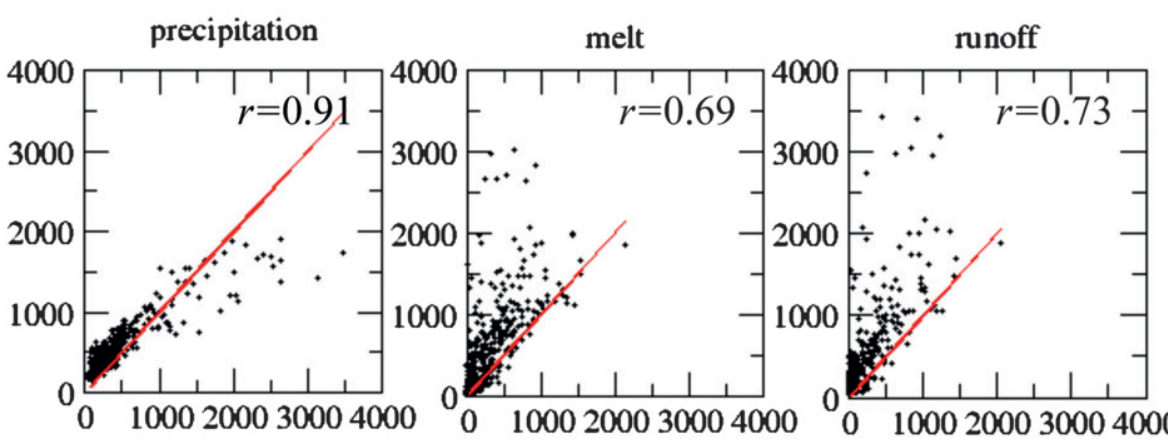

sublimation/evap

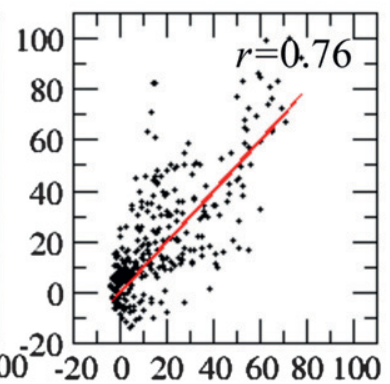

FIG. 8. Maps of precipitation (PR), surface melt (ME), runoff (RU), and sublimation/evaporation (SU) ( $\mathrm{kg} \mathrm{m}^{-2} \mathrm{yr}^{-1}$ ) for (top) CESM (CLM resolution) vs (middle) RACMO2 ( 11-km resolution) averaged over 1960-2005. Elevation contours are plotted every 1000 m; the red contour corresponds to $50 \%$ glacier coverage. For CESM grid cells with at least $1 \%$ glacier coverage have been plotted. The fields are area-weighted averages over the 10 elevation classes. (bottom) Scatterplots are for the corresponding fields after averaging RACMO2 data to the CESM grid; The -abscissa (ordinate) is RACMO2 (CESM) and the red line is the 1:1 fit. For melt and runoff, only points with nonnull RACMO2 values have been plotted. $\left(\mathrm{kg} \mathrm{m}^{-2} \mathrm{yr}^{-1}\right)$.

forcing of precipitation. Also, CESM overestimates precipitation in the west in most of the area between 1000-m and 2000-m height, with rates of more than $700 \mathrm{~kg} \mathrm{~m}^{-2} \mathrm{yr}^{-1}$ at locations where RACMO2 simulates precipitation of 300 to $500 \mathrm{~kg} \mathrm{~m}^{-2} \mathrm{yr}^{-1}$. The RMSE is $274 \mathrm{~kg} \mathrm{~m}^{-2} \mathrm{yr}^{-1}$.

In CESM, rainfall represents a very large fraction $(15 \%)$ of the precipitation over the ice sheet with a total of $127 \pm 19 \mathrm{Gt} \mathrm{yr}^{-1}$. Rainfall is also simulated at high elevations of the ice sheet (not shown), which is unrealistic because the year-round low temperatures in this region. This overestimation of precipitation is due to a model bias in the atmosphere model, which simulates rainfall events at temperatures well below freezing. This model bias has been corrected in the next version of the atmospheric model [the Community Atmosphere Model version 5 (CAM5)]. 


\section{b. Melt and runoff}

The total melt rate amounts to $568 \pm 112 \mathrm{Gt} \mathrm{yr}^{-1}$, which is in the high range of previous model studies (Table 2). Melt rates of more than $1 \mathrm{~kg} \mathrm{~m}^{-2} \mathrm{yr}^{-1}$ occur all over the ice sheet except for the northern half of the area with elevations higher than $2000 \mathrm{~m}$ (Fig. 8). Below $1000 \mathrm{~m}$ the highest melt rates are simulated along the western and southeastern margins. This is also the case for the heights between 1000 and $2000 \mathrm{~m}$, with melt rates of $700-1000 \mathrm{~kg} \mathrm{~m}^{-2} \mathrm{yr}^{-1}$. The lowest melt rates between these heights occur in the north, as in RACMO2 (Fig. 8). The correlation coefficient is 0.73 , and the RMSE is $489 \mathrm{~kg} \mathrm{~m}^{-2} \mathrm{yr}^{-1}$ (Table 2).

CESM simulates runoff all over the ice sheet (Fig. 8). In reality, the low melt rates above $2000 \mathrm{~m}$ and the low temperatures of the snowpack should cause all the available liquid water (defined here as the sum of meltwater and rainfall) to refreeze. However, as explained above, in CESM rainfall over snow surfaces that reach the maximum thickness $H_{\max }$ is prescribed to run off. This maximum thickness is reached during most of the time in the accumulation area. This explains the differences between the runoff maps of CESM and RACMO2 (Fig. 8) in this area. If this area is excluded, the mean bias and RMSE are +414 and $675 \mathrm{~kg} \mathrm{~m}^{-2} \mathrm{yr}^{-1}$.

\section{c. Sublimation/evaporation}

Sublimation/evaporation amounts to $54 \pm 3 \mathrm{Gt} \mathrm{yr}^{-1}$, in the midrange of the values from the regional models shown in Table 2, and very close to RACMO2 values $\left(40 \pm 4 \mathrm{Gt} \mathrm{yr}^{-1}\right)$. Net deposition takes place in the northernmost part over $2000 \mathrm{~m}$ (negative values, Fig. 8). Over most of the other high areas, sublimation rates are

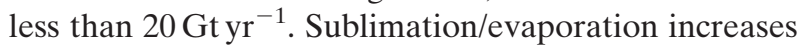
toward the margins and decreases again over part of the ablation zones. The highest values are reached in the south and southwest margins. The agreement with RACMO2 is high $\left(r=0.81, \mathrm{RMSE}=17 \mathrm{~kg} \mathrm{~m}^{-2} \mathrm{yr}^{-2}\right)$.

\section{d. Seasonality and comparison with GRACE data}

Figure 9 (top) illustrates mean daily values of melt, refreezing, precipitation, and sublimation averaged over the ice sheet for the reference period (1960-2005). Snow starts melting in mid-April, reaching maximum melt rates in July and sharply decreasing during August. There is little melt in September and none after October. All snowmelt refreezes during the first month of melt. Maximum refreezing rates take place in the months of higher snowmelt, representing a bit more than one-third of the snowmelt, at the peak of the melt season. Some refreezing occurs in the fall, when the only source of available liquid water is rainfall. Bare ice starts
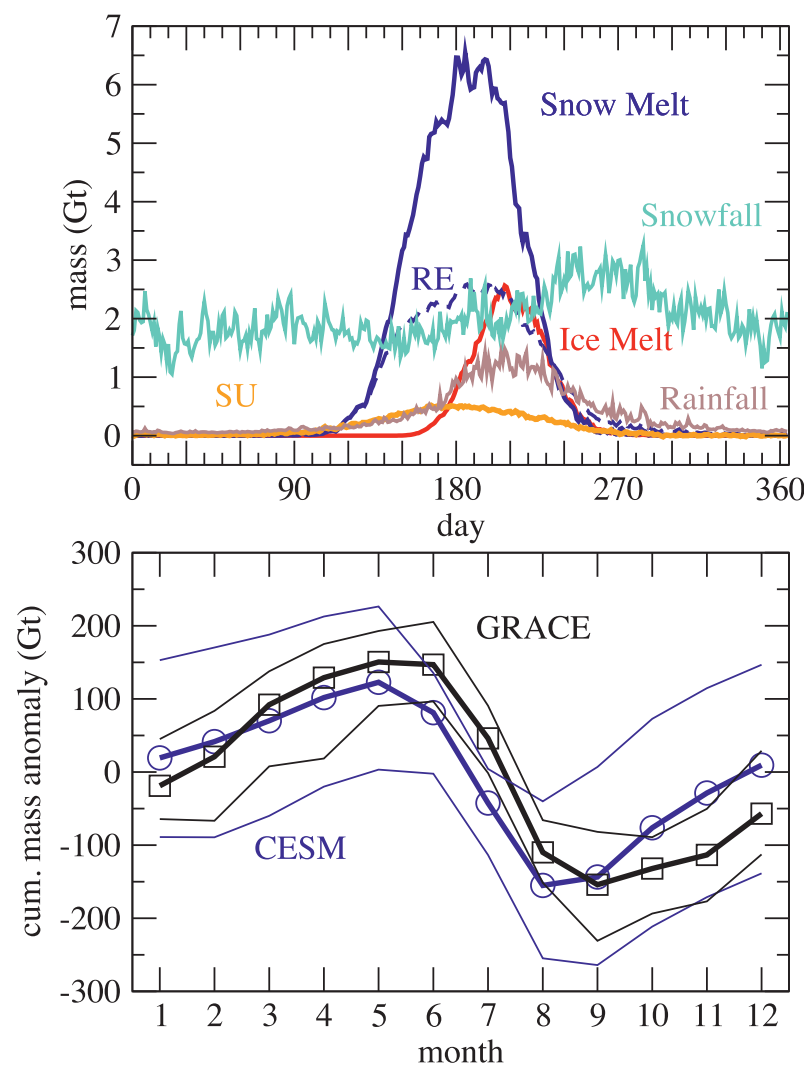

FIG. 9. (top) CESM seasonal cycle of snowmelt, bare ice melt, refreezing, snowfall, rain, and sublimation (Gt). (bottom) Comparison of the seasonal cycle of mass anomalies (Gt) between CESM (blue) and GRACE (black). Thick lines represent 9-yr averages and thin lines represent the maximum and minimum monthly anomalies. Selected periods are 1996-2004 (CESM) and 2003-2011 (GRACE).

melting in early June, with maximum rates in late July. Approximately $90 \%$ of the melt of bare ice takes place in the two months July and August. From September, melt rates of snow and bare ice are similar.

Snowfall is relatively constant throughout the year, with a maximum in late summer and early fall. Rainfall occurs between May and November, with most of it occurring in July and August. Sublimation takes place mostly between March and the end of September, with maximum daily rates of $180 \mathrm{Gt} \mathrm{yr}^{-1}$ in early July.

Figure 9 (lower) compares CESM SMB with data of the GIS mass from GRACE. We use the release 05 data from the Center for Space Research spanning years from 2003 to 2011, with monthly frequency. We applied all common corrections to the data, as in van den Broeke et al. (2009), including a correction for the displacement of the earth's center of mass (Swenson et al. 2008). The cumulative mass anomalies for the Greenland Ice Sheet are derived from the GRACE data using the basin 

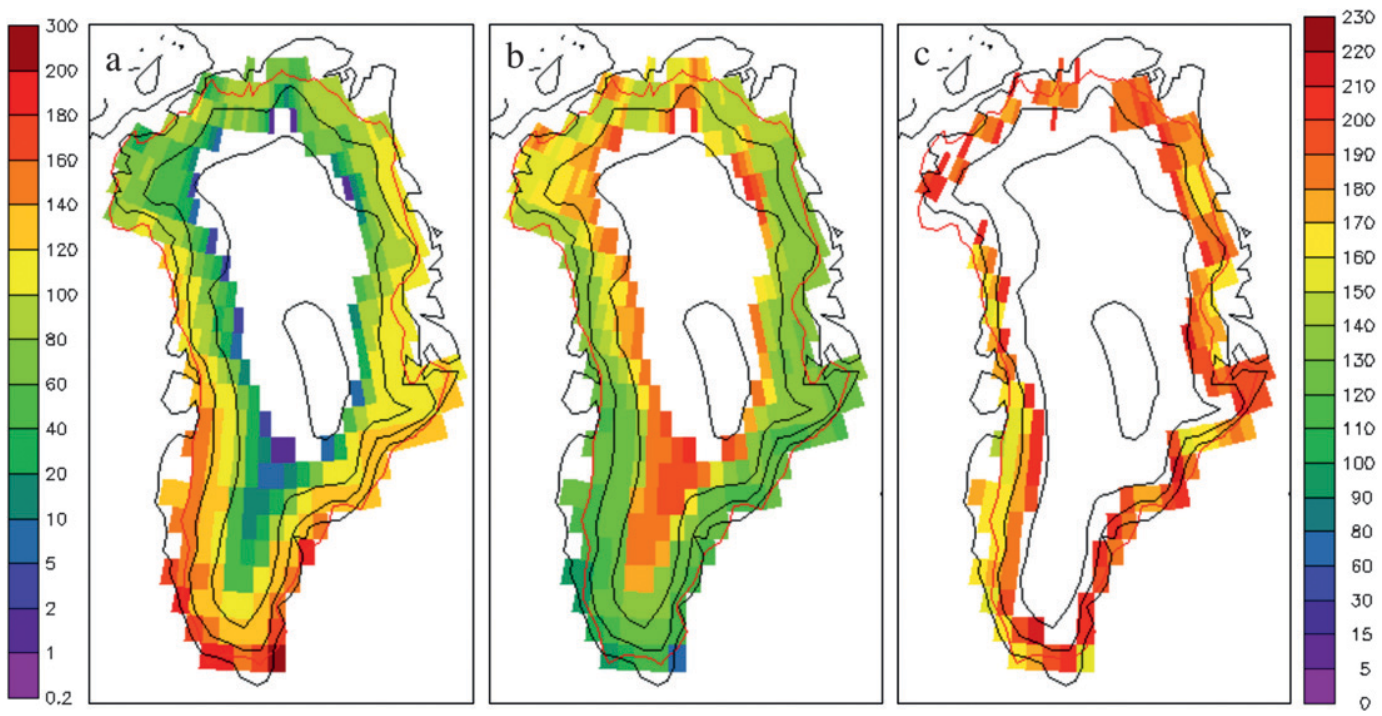

FIG. 10. (a) Number of melt days and (b) first day of melt, with 1 corresponding to 1 Jan (left color scale); and (c) first day of ice melt from daily mean values for 1960-2005 as simulated by CESM (right color scale). The threshold for melt has been set to $1 \mathrm{~kg} \mathrm{~m}^{-2} \mathrm{yr}^{-1}$. Elevation contours are plotted every $1000 \mathrm{~m}$; the red line delimits $50 \%$ ice sheet cover.

method of Wouters et al. (2008). A year-by-year comparison with the CESM is not possible because of internal variability of the model data. For this reason, we compare the seasonal cycle from nine CESM years (1996-2004). It must be noted that the time interval for GRACE is shifted forward with respect to the years from CESM; therefore, seasonal variations could be more influenced by the global warming trend. GRACE data represents cumulative mass anomalies, with monthly frequency. The data has been detrended (quadratic fit). CESM cumulative (surface) mass anomalies have been constructed from monthly SMB fields and detrended (quadratic fit). For this comparison, we assume that ice flux to the ocean is approximately constant throughout the year, as suggested in van den Broeke et al. (2009). For both model and satellite data, monthly anomalies to the annual mean have been constructed for each year. Nineyear-mean anomalies (thick lines) and the maximum and minimum anomalies for each month (thin lines) have been plotted in Fig. 9. The mean cycles are well correlated $(r=0.88)$. The CESM mean cycle (thick blue line) shows its maximum in May, as in GRACE (thick black line), and its minimum in August, a month earlier than GRACE. The amplitude of this cycle is similar in the model and data, with a maximum to minimum anomaly of $278 \mathrm{Gt}$ in CESM (305 Gt in GRACE). Interannual variability in the seasonal cycle is greater in CESM. The modeled mass recovery after the late-summer minimum is somehow stronger in CESM for the mean values, although within the variability range shown by GRACE data.
Figure 10 illustrates the spatial variability in timing and duration of total melt and bare ice melt as modeled by the CESM. Melt starts in early spring in the areas of southern Greenland below $1000 \mathrm{~m}$ and in late April between 1000 and $2000 \mathrm{~m}$. In the northern half of the ice sheet, melt starts in late spring, with the latest inception for the height range between 1000 and $2000 \mathrm{~m}$ taking place in the northwest. Areas between 1000 and $2000 \mathrm{~m}$ begin to melt in mid to late July, roughly at the same time as the areas over $2000 \mathrm{~m}$ in the southern third of the ice sheet. In the other two thirds of the high elevations of the ice sheet melt does not exceed the daily mean threshold of $1 \mathrm{~kg} \mathrm{~m}^{-2} \mathrm{yr}^{-1}$.

The melt season lasts five months in the lower part of the western ablation area and more than six months at some smaller areas in the low south. In eastern Greenland and at elevations between 1000 and $2000 \mathrm{~m}$ of the western ablation area, the melt season lasts almost four months. In the north the season lasts between two and three months, depending on the location. The locations over $2000 \mathrm{~m}$ show a clear south-to-north gradient, with the melt season ranging from almost three months in the southernmost areas to only one day in the northernmost grid point that experiences melt according to the chosen daily mean threshold of $1 \mathrm{~kg} \mathrm{~m}^{-2} \mathrm{yr}^{-1}$.

\section{e. Albedo}

Figure 11 shows the surface albedo at the beginning (April) and peak (July) of the melt season only for the glacier fraction of the grid cells that belong to the ice sheet. These albedo values represent the weighted average over different elevation classes. 

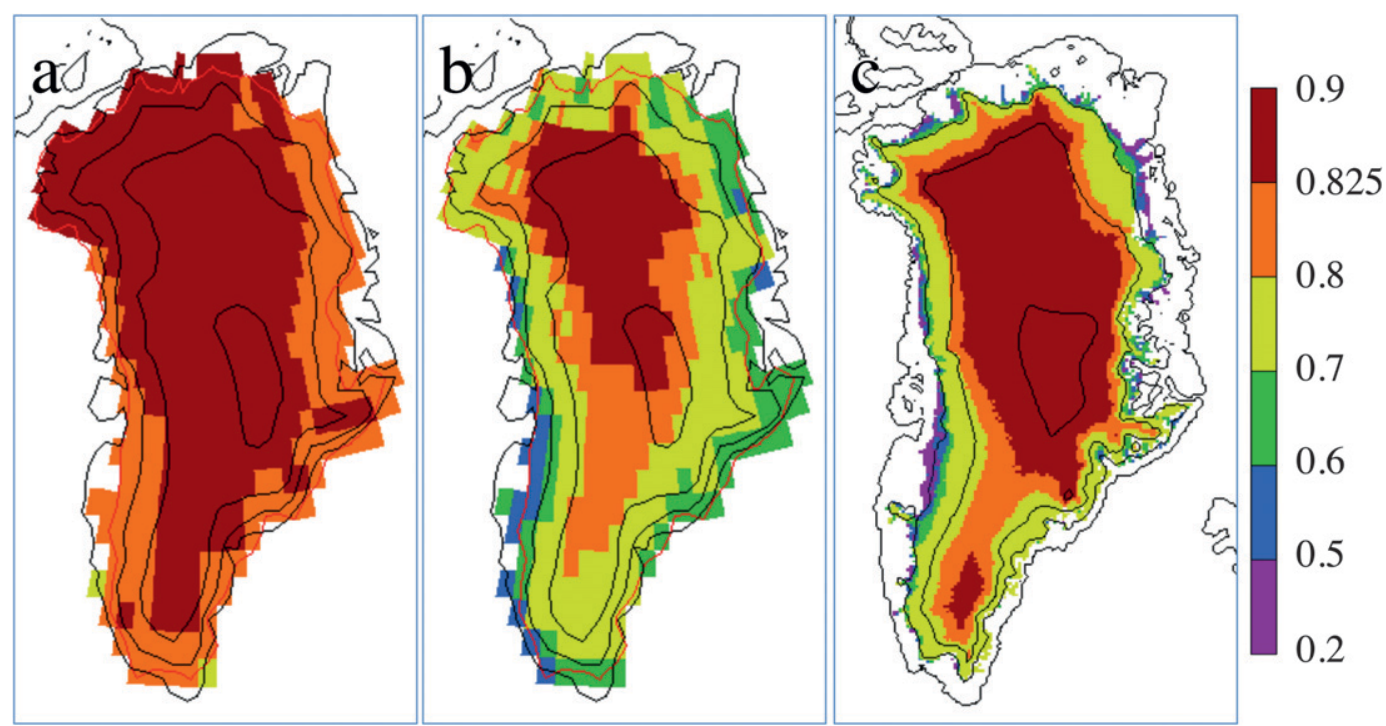

FIG. 11. Map of mean (a) April and (b) July albedos for 1960-2005 as simulated by CESM. (c) July albedo from RACMO2 for the same years. Elevation contours are plotted every $1000 \mathrm{~m}$; the red line delimits $50 \%$ ice sheet cover.

The CESM mean albedo over the ice sheet changes from 0.84 in April to 0.76 in July. This is higher than RACMO2 by 0.02 in both months. At the beginning of the melt season in April, the surface albedo over the ice sheet is above 0.825 at the locations where no melt has happened yet and slightly lower at the locations where there has been some melt, in the western and eastern margins below $2000 \mathrm{~m}$ (Fig. 10a). RACMO2 shows a uniform pattern of albedo exceeding 0.825 (not shown). At the peak of the melt season, albedo has dropped most in the western ablation area, reaching values close to 0.5 , which are typical for bare ice (Fig. 10b). With the exception of the northern margin, most of the areas below $1000 \mathrm{~m}$ show albedo values below 0.7 . Above $2000 \mathrm{~m}$ the albedo is that of dry snow $(>0.825)$ in the northern half and decreases southward until reaching values close to 0.7 , which are typical for wet snow in the southernmost areas.

\section{SMB variability and trends}

The mean surface mass balance for the period 18502005 is $386 \pm 107 \mathrm{Gt} \mathrm{yr}^{-1}$. The preindustrial value, corresponding to years 55 to 100 of the preindustrial simulation, is similar for the mean with a much smaller standard deviation: $390 \pm 66 \mathrm{Gt} \mathrm{yr}^{-1}$. The map of the preindustrial SMB (Fig. 12) is similar to the map for 1960-2005 (Fig. 6) but with smaller ablation areas $(8 \%$ of the ice sheet surface).

Figure 13a displays the time evolution of the SMB, precipitation, melt, and runoff during 1850-2005. The net surface mass balance shows a negative trend of $-0.75 \mathrm{Gt} \mathrm{yr}^{-2}$, significant at the $95 \%$ level. Both runoff and precipitation show positive trends: +0.87 and $+0.14 \mathrm{Gt} \mathrm{yr}^{-2}$, respectively, with only the runoff trend being significant. The SMB ranges between 17 and $710 \mathrm{Gt} \mathrm{yr}^{-1}$. The second and third lowest SMB values are both reached after 1990. For all individual years in the period $1998-2005$, the modeled SMB is below the 1850-2005 mean. The trend in summer near-surface temperature averaged over the whole ice sheet (Fig. $13 \mathrm{~b}$ ) is $0.0086^{\circ} \mathrm{C} \mathrm{yr}^{-1}$, which is significant. The SMB over Greenland increases from 1991 to 1992 in response to the Mt Pinatubo eruption. Temperature, runoff, and melt decrease between these two years, while precipitation increases.

The standard deviations of the different integrated terms of the SMB compare well with RACMO2 (Table 1), indicating a similar variability in both models.

Figure 14 shows a map of SMB trends in CESM and RACMO. During 1960-2005 CESM has negative trends of more than $10 \mathrm{~kg} \mathrm{~m}^{-2} \mathrm{yr}^{-1}$ in the lower part of most of the ablation areas except in the northeast, which has positive trends of $\sim 3 \mathrm{~kg} \mathrm{~m}^{-2} \mathrm{yr}^{-1}$ (Fig. 14b). These trends in the ablation areas are similar to those modeled by RACMO2 (Fig. 14c). RACMO2 does not model the positive trend in the northeast. Instead, positive trends are modeled at some areas along the western part of the ice sheet. This mismatch between models is most likely attributable to the differences in snowfall related to natural variability (RACMO2 is forced with reanalysis data). The 19602005 negative trend in the ablation areas is also present when considering the whole simulation period (Fig. 14a). The trend in the northeast has the opposite sign. 


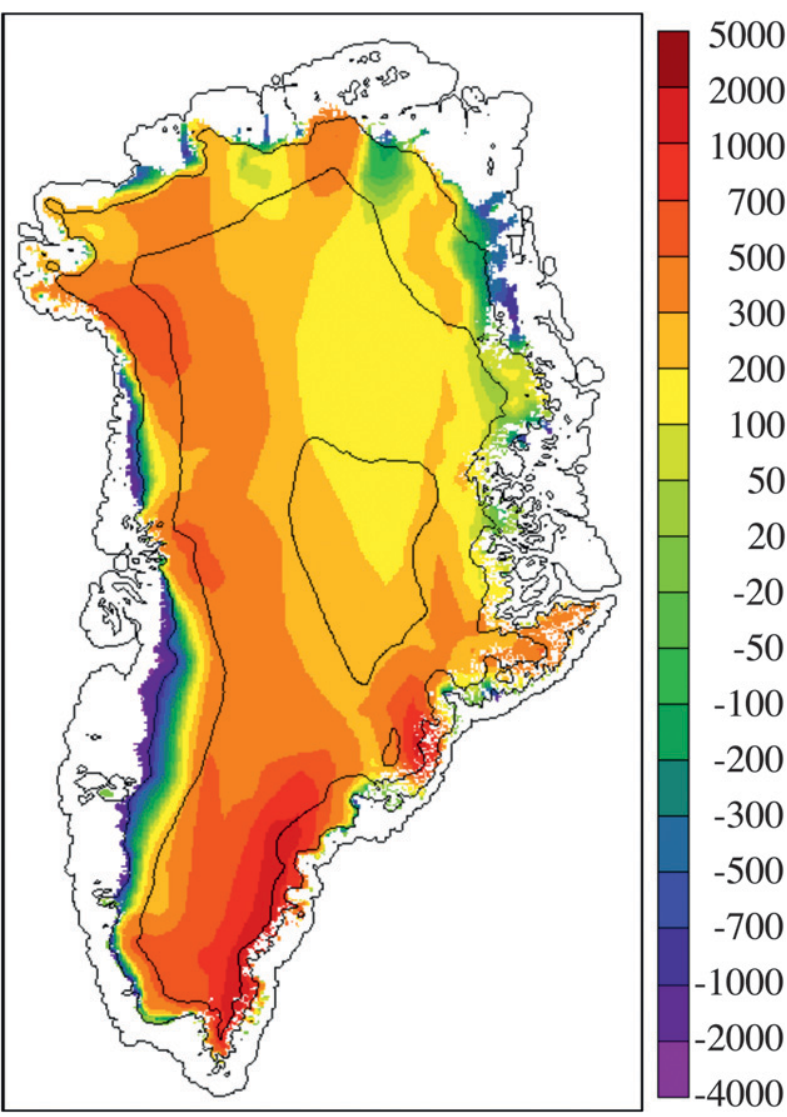

FIG. 12. SMB $\left(\mathrm{kg} \mathrm{m}^{-2} \mathrm{yr}^{-1}\right)$ of the preindustrial ice sheet (average of years 55-100) at 5-km resolution.

\section{Summary and conclusions}

We have described the performance of the Community Earth System Model (CESM) in the calculation of the surface mass balance (SMB) of the Greenland Ice Sheet. The CESM includes a completely new ice sheet component. The SMB is calculated in the land model at its coarse horizontal resolution with the same snow physics that is used in the model for nonglaciated surfaces. Over glaciated surfaces, the SMB is calculated at several prescribed elevations and then downscaled to a finer grid. In this study, the finer grid has a horizontal resolution of $5 \mathrm{~km}$. This resolution is required for an adequate modeling of the SMB gradients at the margins of the Greenland Ice Sheet (van den Broeke et al. 2008a).

The simulated near-surface climate of the ice sheet was evaluated against output from the regional climate model RACMO2. The near-surface temperature over the ice sheet is in good agreement with RACMO2 but with higher temperatures over $2500 \mathrm{~m}$ in CESM. The radiation and turbulent fluxes from CESM compare well with RACMO over the ice sheet but show large biases over the tundra regions.
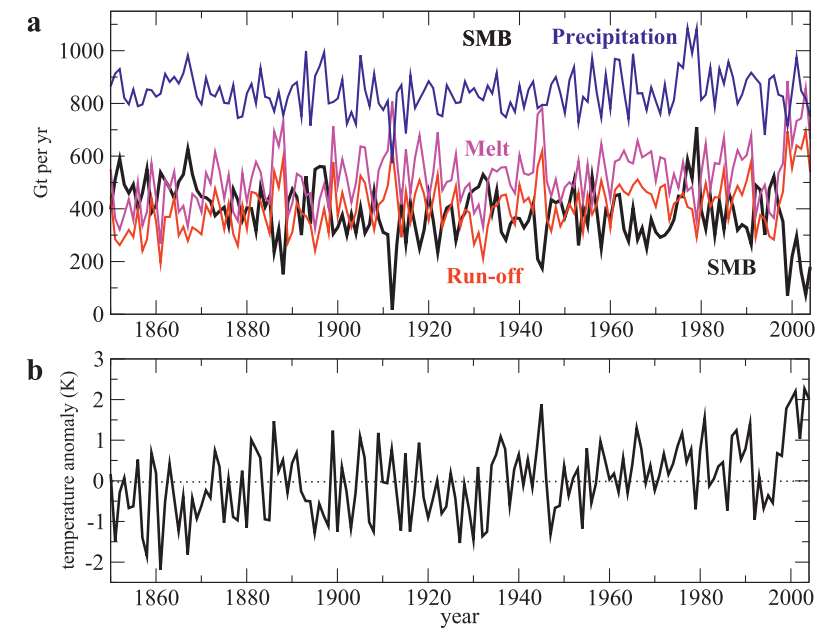

FIG. 13. 1850-2005 time series of (a) SMB, runoff, melt, and precipitation $\left(\mathrm{Gt} \mathrm{yr}^{-1}\right)$ and (b) summer near-surface temperature anomalies with respect to the period average. Fields have been integrated over the Greenland Ice Sheet.

The surface albedo over the ice sheet changes from nearly uniform values before the beginning of the melt season to a very heterogeneous map at the peak of the season in July, with maximum values of more than 0.825 in the northern half over $2000 \mathrm{~m}$ and minimum values close to the albedo of bare ice $(\sim 0.5)$ in the lowest parts of the western ablation area. Intermediate values close to 0.7 , which are typical of wet snow, are modeled at heights between 1000 and $2000 \mathrm{~m}$. Since the surface energy balance is dominated by radiation fluxes (van den Broeke et al. 2008a,b), changes in surface albedo have a profound impact on the energy available for melt. The tight relationship between mass balance processes (snowfall, rainfall, snowmelt, refreezing, and bare ice melt) and albedo is well modeled in the CESM, enabling a correct coupling between SMB and local climate.

Melt rates are greatest over the western, northeast, and southeast ablation areas and decrease strongly with height, with melt rates below $1 \mathrm{~kg} \mathrm{~m}^{-2} \mathrm{yr}^{-1}$ in the northern half above $2000 \mathrm{~m}$. Runoff peaks at the same locations as melt. Over $2000 \mathrm{~m}$, runoff is unrealistically large owing to the model constraint of limiting the snow thickness to a prescribed value and the assumption that additional rain runs off.

Rainfall is unrealistically simulated in the model to occur over the interior of the ice sheet. In addition, the total amount of rainfall is too large. This rainfall excess has an impact in several surface mass balance processes. It represents an artificial source of mass in regions where the snowpack has a thickness $H$ between $0 \mathrm{~m}$ and $H_{\max }$ of 1-m LWE, such as the percolation area and in the ablation area early in the melt season before bare ice is 

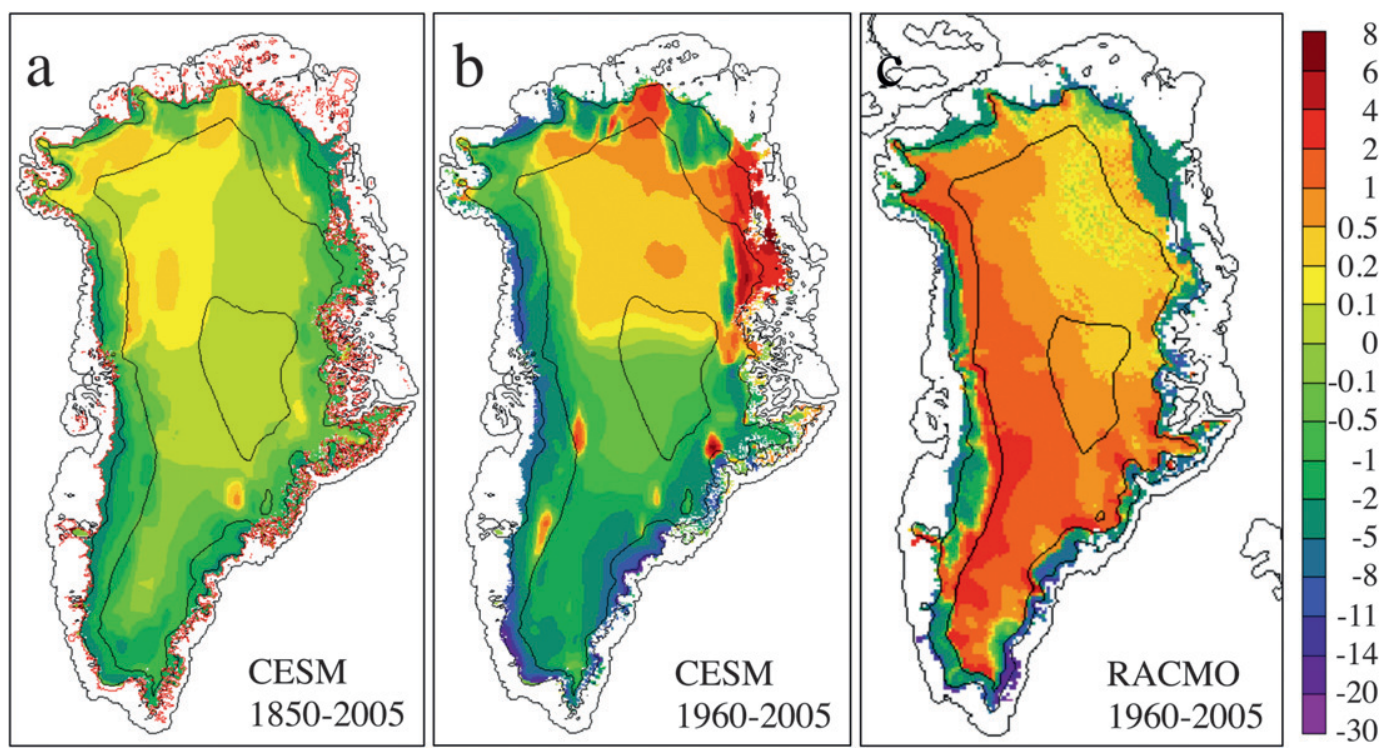

FIG. 14. SMB trends $\left(\mathrm{kg} \mathrm{m}^{-2} \mathrm{yr}^{-2}\right)$ at 5-km resolution for (a) 1850-2005 and (b) 1960-2005; and (c) as simulated by RACMO2 for 1960-2005.

exposed. At these locations, rainfall reduces the refreezing capacity of the snowpack, which warms when rainfall freezes. Also, rainfall reduces surface albedo, causing transitions from the high albedo for dry snow to low albedo for wet snow.

The simulated melt season starts in April and lasts until September. Northern areas start melting in late May. The amount of refreezing is roughly equal to the amount of melt during the first month of the melt season. Total refreezing represents $35 \%$ of the available liquid water, which is the sum of rainfall and melt.

A major limitation in the modeling of refreezing in the CESM is the lack of a true snowpack model over the ice sheet. In the CLM snowpack model, the maximum thickness of snow cannot exceed a prescribed value $H_{\max }$. The thickness $H_{\max }$ cannot be set to high values since, otherwise, the model cannot initialize with a correct distribution of ablation areas because negative SMB is only modeled at locations where the spring snow layer is completely melted and bare ice is exposed. While the approach in CESM of having a snowpack model in common with nonglaciated surfaces benefits from the advantages of model consistency and a more efficient coupling between atmosphere and land, a true firn model would provide a more adequate treatment of refreezing.

In a simulation covering 1850-2005, the simulated SMB variability agrees well with regional models. The SMB responds adequately to external forcing, for instance to volcanic eruptions such as the Pinatubo eruption in 1991. During 1960-2005, the SMB shows negative trends over the western and northern ablation areas, as well as in the northeast margin, in agreement with RACMO2.

After evaluating the processes included in the model and comparing to regional climate models, we conclude that the CESM is the first global climate model that is capable of realistically simulating the surface mass balance of the Greenland Ice Sheet, in spite of limitations imposed by the coarse horizontal resolution. The good match between CESM and state-of-the-art regional models and observations is not attributed to tuning (as in temperature-based melt index methods) but to adequate physical modeling of surface mass and energy balance processes, including albedo evolution, and an effective downscaling scheme. As shown in this study, a good simulation of the surface climate over Greenland is also strongly tied to a correct simulation of surface mass balance processes. Models with a weaker coupling between surface climate and surface mass balance are likely to suffer from biases in their simulation of the SMB and sensitivity to climate change.

Acknowledgments. M. Vizcaíno was funded via NSF Grant ATM-0917755 to UC Berkeley and a Marie Curie International Incoming Fellowship within the 7th European Community Framework (EC FP7) Programme (FP7-PEOPLE-2010-IIF-272956). W. Lipscomb was supported by the Scientific Discovery through Advanced Computing (SciDAC) project funded by the U.S. Department of Energy, Office of Science, Advanced Scientific Computing Research and Biological and Environmental Research. The Los Alamos National 
Laboratory is operated by the DOE National Nuclear Security Administration under Contract DE-AC5206NA25396. Additional support was provided by NSF through Awards ANT-1103686 (for W. Sacks) and a Small Grant for Exploratory Research (for W. Lipscomb). B. Wouters is funded by a Marie Curie International Outgoing Fellowship within the EC FP7 Programme (FP7PEOPLE-2011-IOF-301260). The CESM project is supported by the National Science Foundation and the Office of Science (BER) of the U.S. Department of Energy. Computing resources were provided by the Climate Simulation Laboratory at the NCAR Computational and Information Systems Laboratory (CISL), sponsored by the National Science Foundation and other agencies. The CMIP5 simulations used in this research were enabled by CISL compute and storage resources. Bluefire, a 4064-processor IBM Power6 resource with a peak of 77 TeraFlops, provided more than 7.5 million computing hours, the GLADE high-speed disk resources provided 0.4 PetaBytes of dedicated disk and the CISL 12-PB HPSS archive provided over 1 PetaByte of storage in support of this research project. In addition, this work used resources of the Oak Ridge Leadership Computing Facility, located in the National Center for Computational Sciences at Oak Ridge National Laboratory, which is supported by the Office of Science of the Department of Energy under Contract DE-AC05-00OR22725. Janneke Ettema provided RACMO2 data from a previous version for preliminary evaluation of CESM. GRACE data were provided by Bert Wouters. J. Ettema, W. J. van de Berg, J. Lenaerts, and X. Fettweis are thanked for insightful discussions about the surface mass balance of the Greenland Ice Sheet.

\section{REFERENCES}

Anderson, E. A., 1976: A point energy and mass balance model of a snow cover. NOAA Tech. Rep. NWS 19, 172 pp.

Bales, R. C., and Coauthors, 2009: Annual accumulation for Greenland updated using ice core data developed during 2000-2006 and analysis of daily coastal meteorological data. J. Geophys. Res., 114, D06116, doi:10.1029/2008JD011208.

Bamber, J. L., R. L. Layberry, and S. Gogineni, 2001: A new ice thickness and bed data set for the Greenland Ice Sheet: 1. Measurement, data reduction, and errors. J. Geophys. Res., 106 (D24), 33 773-33780.

Box, J. E., and Coauthors, 2006: Greenland Ice Sheet surface mass balance variability (1988-2004) from calibrated polar MM5 output. J. Climate, 19, 2783-2800.

Cogley, J. G., 2004: Greenland accumulation: An error model. J. Geophys. Res., 109, D18101, doi:10.1029/2003JD004449.

Ettema, J., M. van den Broeke, E. van Meijgaard, W. J. van de Berg, J. Bamber, J. Box, and R. Bales, 2009: Higher surface mass balance of the Greenland Ice Sheet revealed by highresolution climate modeling. Geophys. Res. Lett., 36, L12501, doi:10.1029/2009GL038110. $-\longrightarrow,-,-\longrightarrow,-$, and,$- 2010 \mathrm{a}$ : Climate of the Greenland Ice Sheet using a high-resolution climate model. Part 1: Evaluation. Cryosphere, 4, 529-544.

,,,--- and 2010b: Climate of the Greenland Ice Sheet using a high-resolution climate model. Part 2: Nearsurface climate and energy balance. Cryosphere, 4, 529544.

Fettweis, X., 2007: Reconstruction of the 1979-2006 Greenland Ice Sheet surface mass balance using the regional climate model MAR. Cryosphere, 1, 21-40.

_-, M. Tedesco, M. van den Broeke, and J. Ettema, 2011: Melting trends over the Greenland Ice Sheet (1958-2009) from spaceborne microwave data and regional climate models. Cryosphere, 5, 359-375, doi:10.5194/tc-5-359-2011.

Flanner, M. G., and C. S. Zender, 2006: Linking snowpack microphysics and albedo evolution. J. Geophys. Res., 111, D12208, doi:10.1029/2005JD006834.

Hanna, E., P. Huybrechts, I. Janssens, J. Cappelen, K. Steffen, and A. Stephens, 2005: Runoff and mass balance of the Greenland Ice Sheet: 1958-2003. J. Geophys. Res., 110, D13108, doi:10.1029/2004JD005641.

— , and Coauthors, 2008: Increased runoff from melt from the Greenland Ice Sheet: A response to global warming. J. Climate, 21, 331-341.

Hunke, E. C., 2010: Thickness sensitivities in the CICE sea ice model. Ocean Modell., 34, 137-149, doi:10.1016/j.ocemod.2010.05.004.

Hurrell, J., and Coauthors, 2013: The Community Earth System Model: A framework for collaborative research. Bull. Amer. Meteor. Soc., in press.

Jahn, A., and Coauthors, 2012: Late-twentieth-century simulation of Arctic sea ice and ocean properties in the CCSM4. J. Climate, 25, 1431-1452.

Joughin, I., E. Rignot, C. E. Rosanova, B. K. Lucchitta, and J. Bohlander, 2003: Timing of recent accelerations of Pine Island Glacier, Antarctica. Geophys. Res. Lett., 30, 1706, doi:10.1029/2003GL017609.

Lenaerts, J. T. M., and M. R. van den Broeke, 2012: Modeling drifting snow in Antarctica with a regional climate model: 2. Results. J. Geophys. Res., 117, D05109, doi:10.1029/2010JD015419.

$\longrightarrow,-$, J. H. van Angelen, E. van Meijgaard, and S. J. Déry, 2012: Drifting snow climate of the Greenland Ice Sheet: A study with a regional climate model. Cryosphere, 6, 891-899, doi:10.5194/tc-6-891-2012.

Lipscomb, W., and Coauthors, 2013: Implementation and initial evaluation of the Glimmer Community Ice Sheet Model in the Community Earth System Model. J. Climate, 26, 73527371.

Mikolajewicz, U., M. Groeger, E. Maier-Reimer, G. Schurgers, A. Winguth, and M. Vizcaino, 2007: Long-term effects of anthropogenic $\mathrm{CO}_{2}$ emissions simulated with a complex earth system model. Climate Dyn., 28, 599-633, doi:10.1007/ s00382-006-0204-y.

Neale, R. B., J. Richter, S. Park, P. H. Lauritzen, S. J. Vavrus, P. J. Rasch, and M. Zhang, 2013: The mean climate of the Community Atmosphere Model (CAM4) in forced SST and fully coupled experiments. J. Climate, 26, 5150-5168.

Oleson, K., and Coauthors, 2010: Technical description of version 4.0 of the Community Land Model (CLM). NCAR Tech. Note NCAR/TN-478+STR, 257 pp.

Rae, J. G. L., and Coauthors, 2012: Greenland Ice Sheet surface mass balance: Evaluating simulations and making projections with regional climate models. Cryosphere, 6, 1275-1294, doi:10.5194/tc-6-1275-2012. 
Ridley, J. K., P. Huybrechts, J. M. Gregory, and J. A. Lowe, 2005: Elimination of the Greenland Ice Sheet in a high $\mathrm{CO}_{2}$ climate. J. Climate, 18, 3409-3427.

Rignot, E., and P. Kanagaratnam, 2006: Changes in the velocity structure of the Greenland Ice Sheet. Science, 311, 986990.

— , J. L. Bamber, M. R. van den Broeke, C. Davis, Y. Li, W. J. van de Berg, and E. van Meijgaard, 2008a: Recent Antarctic mass loss from radar interferometry and regional climate modeling. Nat. Geosci., 2, 106-110.

_ J. E. Box, E. Burgess, and E. Hanna, 2008b: Mass balance of the Greenland Ice Sheet from 1958 to 2007. Geophys. Res. Lett., 35, L20502, doi:10.1029/2008GL035417.

Rutt, I., M. Hagdorn, N. J. R. Hulton, and A. J. Payne, 2009: The Glimmer Community Ice Sheet Model. J. Geophys. Res., 114, F02004, doi:10.1029/2008JF001015.

Scambos, T. A., J. A. Bohlander, C. A. Shuman, and P. Skvarca, 2004: Glacier acceleration and thinning after ice shelf collapse in the Larsen B embayment, Antarctica. Geophys. Res. Lett., 31, L18402, doi:10.1029/2004GL020670.

Shepherd, A., and D. Wingham, 2007: Recent sea-level contributions of the Antarctic and Greenland Ice Sheets. Science, 315, 1529-1532.

Simmons, A. J., S. M. Uppala, D. P. Dee, and S. Kobayashi, 2007: ERA-Interim: New ECMWF re-analysis products from 1989 onwards. ECMWF Newsletter, No. 110, ECMWF, Reading, United Kingdom, 29-35.

Smith, R. D., and Coauthors, 2010: The Parallel Ocean Program (POP) reference manual: Ocean component of the Community Climate System Model (CCSM). Los Alamos National Laboratory Tech. Rep. LAUR-10-01853, 141 pp. [Available online at http://www.cesm.ucar.edu/models/cesm1.0/pop2/ doc/sci/POPRefManual.pdf.]

Steffen, K., S. V. Nghiem, R. Huff, and G. Neumann, 2004: The melt anomaly of 2002 on the Greenland Ice Sheet from active and passive microwave satellite observations. Geophys. Res. Lett., 31, L20402, doi:10.1029/2004GL020444.

Swenson, S., D. Chambers, and J. Wahr, 2008: Estimating geocenter variations from a combination of GRACE and ocean model output. J. Geophys. Res., 113, B08410, doi:10.1029/ 2007JB005338.

Uppala, S. M., and Coauthors, 2005: The ERA-40 Re-Analysis. Quart. J. Roy. Meteor. Soc., 131, 2961-3012. van Angelen, J. H., J. T. M. Lenaerts, S. Lhermitte, X. Fettweis, P. Kuipers Munneke, M. R. van den Broeke, and E. van Meijgaard, 2012: Sensitivity of Greenland Ice Sheet surface mass balance to surface albedo parameterization: A study with a regional climate model. Cryosphere, 6, 1175-1186, doi:10.5194/tc-6-1175-2012.

van den Broeke, M., P. Smeets, J. Ettema, and P. K. Munneke, 2008a: Surface radiation balance in the ablation zone of the west Greenland Ice Sheet. J. Geophys. Res., 113, D13105, doi:10.1029/2007JD009283.

$,-\longrightarrow,-$ C. van der Veen, R. van de Wal, and J. Oerlemans, 2008b: Partitioning of melt energy and meltwater fluxes in the ablation zone of the west Greenland Ice Sheet. Cryosphere, 2, 179-189.

_ , and Coauthors, 2009: Partitioning recent Greenland mass loss. Science, 326, 984-986.

van de Wal, R. S. W., W. Boot, C. J. P. P. Smeets, H. Snellen, M. R. van den Broeke, and J. Oerlemans, 2012: Twenty-one years of mass balance observations along the K-transect, west Greenland. Earth Syst. Sci. Data, 4, 31-35, doi:10.5194/ essd-4-31-2012.

Velicogna, I., 2009: Increasing rates of ice mass loss from the Greenland and Antarctic Ice Sheets revealed by GRACE. Geophys. Res. Lett., 36, L19503, doi:10.1029/2009GL040222.

Vizcaíno, M., U. Mikolajewicz, M. Gröger, E. Maier-Reimer, G. Schurgers, and A. M. E. Winguth, 2008: Long-term ice sheet-climate interactions under anthropogenic greenhouse forcing simulated with a complex earth system model. Climate Dyn., 31, 665-690.

,-- J. Jungclaus, and G. Schurgers, 2010: Climate modification by future ice sheet changes and consequences for ice sheet mass balance. Climate Dyn., 34, 301-324.

Wientjes, I. G. M., and H. Oerlemans, 2010: An explanation for the dark region in the western melt zone of the Greenland Ice Sheet. Cryosphere, 4, 261-268.

Wouters, B., D. Chambers, and E. J. O. Schrama, 2008: GRACE observes small-scale mass loss in Greenland. Geophys. Res. Lett., 35, L20501, doi:10.1029/2008GL034816.

Zwally, H. J., M. B. Giovinetto, J. Li, H. G. Cornejo, M. A. Beckley, A. C. Brenner, J. L. Saba, and D. Yi, 2005: Mass changes of the Greenland and Antarctic Ice Sheets and shelves and contributions to sea-level rise: 1992-2002. J. Glaciol., 51, 509-527. 